\title{
On Schmarda's lost earthworm and some newly found New Zealand species (Oligochaeta: Megadrilacea: Lumbricidae, Acanthodrilidae, Octochaetidae, \& Megascolecidae s. stricto)
}

\author{
Robert J. Blakemore* \\ Department of Engineering Science, University of Auckland(Te Whare Wānanga o Tāmaki Makaurau) (UA), \\ New Zealand(NZ), currently National Institute of Biological Research(NIBR) Incheon, Korea \\ *Correspondent: rob.blakemore@gmail.com
}

\begin{abstract}
The saga of Megascolides orthostichon (Schmarda, 1861)-the first native worm described from Australasiacontinues as its type-locality is unequivocally returned from Hobart, Tasmania to Mt Wellington, Auckland where a brief survey failed to unearth it. Since it has not been seen for $150 \mathrm{yrs}$, it may qualify under NZTCS or IUCN classification as 'Nationally Critical' if not 'Extinct'. New reports are for exotic Megascolecidae Anisochaeta kiwi sp. nov. and A. kiwi mihi sub-sp. nov. plus addition to the NZ faunal list of Australian Anisochaeta macleayi (Fletcher, 1889) that, due to its wide distribution in Australia and now New Zealand, may be a candidate model-species suitably resilient for eco-toxicological culture and monitoring. For holarctic Lumbricidae, new records are of Dendrobaena attemsi (Michaelsen, 1903) and the Murchieona muldali (Omodeo, 1956) morph or subspecies of M. minuscula (Rosa, 1906), neither lumbricid previously uncovered in Asia/Australasia. Also found for the first time outside its East Asian homeland is Eisenia japonica (Michaelsen, 1892) (which is compared to Japanese E. japonica hiramoto sub-sp. nov. and to $E$. anzac Blakemore, 2011). Records of these exotics plus recent new native species described by the authorincluding two, Rhododrilus mangamingi and Deinodrilus orcus spp. novae, herein-raise the numbers of megadriles known from New Zealand to 228 (sub-)species in five families. Preliminary mtDNA COI sequence barcodes are presented. Genus Tokea Benham, 1904 is revived on its lack of dorsal pores, losing or gaining some species with Megascolides M'Coy, 1878. An updated checklist of all 228 New Zealand taxa is appended.
\end{abstract}

Keywords: exotic invasives, geothermal invertebrate survey, native endemics, Redbook extinctions

\section{INTRODUCTION}

Lee (1959), while describing New Zealand's 192 earthworm species, had thought Hypogaeon orthostichon Schmarda, 1861 was incertae sedis as it was previously referred to the genus Megascolides by Beddard(1892) or to Notoscolex by Michaelsen (1900: 188). On the basis of its supposed prostate tubularity, the former option was more acceptable to Blakemore (2000c) wherein it was assumed to be Tasmanian rather than a New Zealander on the authorities of Capt. Hutton, Auckland-born J.J. Fletcher and, initially, Sir W.B. Benham. Its type-locality given by Schmarda was "Mt Wellington, New Zealand", but Lee (1959: 349; 1962: 176) remarked that there had always been doubt as to whether this species was actually collected from NZ or whether it might have been from the more prominent Mt Wellington at Hobart, Tasmania. The main support for this latter argument was given by
Fletcher (1886: 534) who, in the opening paper of his series of reports on Australian earthworms, stated:

"Up to the present time only three [now known to be exotic] species of earthworms have been described from Australia, with a fourth (Lumbricus orthostichon, Schmarda) from Tasmania. This last was originally described as from New Zealand, but this locality, on the authority of Captain Hutton, is incorrect."

Captain F.W. Hutton, curator of Otago Museum and contemporary compatriot of Sir W.B. Benham, reported (Hutton 1878: 317 footnote) that: "L. orthostichon Schmarda, is stated to come from New Zealand by mistake; its proper habitat is Tasmania."

This suggestion: that the real source whence Schmarda obtained his worm was well-known Mount Wellington $(1,270 \mathrm{~m}$ high) above Hobart and that the words "New Zealand" were in error, caused Benham to refer to it in a meeting at Hobart in 1902 as a "neglected Tasmanian earthworm", however Benham soon argued the converse 
(in papers now readily accessible online) with the stated reason for his turn around (Benham 1904a: 284; 1904b: 256) being:

"Schmarda visited Auckland, and at that period (1860, about) it is probable that little or no cultivation had then been carried out on this small mountain".

Ludwig K. (Karl) Schmarda (1819-1908) certainly collected polychaete specimens from littoral sands at Auckland, and his three volume account of his 1853-1857 World travels gives this description (Schmarda 1861b: 194):

"Ein charakteristischer Zug in der Configuration der Landschaft um Auckland sind die Vulcane, die meistens vollkommene Kegel von 300 bis 600 Fu $\beta$ Höhe bilden. Von einem derselben, in der Nähe von Howik, übersieht man neun Kegel auf einmal; alle, die ich besuchte, hatten Krater in Form vollkommener Minentrichter." [A characteristic feature of the countryside around Auckland are volcanoes forming the most perfect cones 300-600 ft (100$200 \mathrm{~m}$ ) high. From one of them, near Howick, nine cones may be overlooked at one time, all that I visited had perfect craters].

Volcanic Mount Wellington $(137 \mathrm{~m})$ is one of the largest in area of Auckland's monogenic basaltic field of 50 scoria cones and the most prominent shortly south-east towards the Howick suburb where much smaller (55 m) Mt Pigeon is also found. Thus is seems Schmarda visited and collected around this site, an erstwhile Māori $p \bar{a}$, indeed several other cones may be seen from the summit of Mt Wellington to this day (pers. obs.). Conversely, there is no record that Schmarda went to Tasmania, the closest he came being the Bass Straits off Melbourne. Furthermore, survey by the current author of Hobart's Mt Wellington in 1996 failed to locate this species (yet several others were present-see Blakemore, 2000c). The conclusion therefore is that the home location of M. orthostichon is not Hobart, Tasmania-rather it is restored to Auckland's Mt Wellington and this species reassumes the mantle of first earthworm scientifically described from New Zealand.

To help determine the fate of this misplaced species, a short excursion was organized. Collection at this locality, as well as incidentally in the region of Taupo-Wairakei, unearthed several new records of exotic species, by default the subjects of this report.

Putting NZ earthworm taxonomy in context: the revised fauna lists and taxonomic changes invoked by Blakemore (1999; 2000a; 2000b; 2000c; 2004; 2006; 2008; 2010a; 2011b) updated those compiled by Lee (1959) and Martin (1977), the latter only concerning exotic lumbricids. A total of 192 species in 34 genera and just two families were provided in Lee (1959) while most recent contributions by Blakemore (2010a; 2011b) increased the species tally to 222 species in five families, including notice of some of the exotics detailed herein. The present revision raises the NZ list to approximately 228 (sub-) species comprising 187 natives, 34 exotics [including overlooked species, e.g. Dichogaster modiglianii (Rosa, 1896) as reported by Ude (1905) and Thomson (1922), and a couple of other doubtful alien exotics' reports], plus seven taxa that for various reasons are difficult to attribute to either category (Appendix II).

Deficiencies in nomenclature and taxonomy advice in the genetic cladogram of Buckley et al. (2011), that mainly concerned 33 named natives but did not provide any novel taxonomic descriptions and only inadvertently listed NZ exotics, were already advised to an online pre-publication in 2010 and in Blakemore (2011). Nonetheless, future co-operation is advised as a duty of Science to resolve the taxonomy and inventory of both natives and exotics in New Zealand and to investigate relationship with taxa endemic to Australia and Oceania as well as those introduced from Europe, Asia or elsewhere by chance.

All NZ exotics are included in the 150 or so known interloper species-the so-called 'Cosmopolitan Earthworms'as fully described and figured with their ecology, synonymies and progressively updated global distributions in Blakemore (2002; 2008; 2010b, in prep.).

\section{Materials And Methods}

A brief resurvey expedition was mounted to Mt. Wellington, Auckland on $14^{\text {th }}$ October, 2011, more than 150 years after Schmarda's visit. Findings are presented here combined with taxonomic history of the species in question:-Megascolides orthostichon.

Serendipitous surveys were also conducted when opportunity permitted at likely geothermal "hot-spots" in the Taupo-Wairakei region, and at Auckland's Domain periodically over a couple of months and on a limited budget with funding unforthcoming.

Specimens were anaesthetized (in dilute alcohol), fixed in $80 \%$ ethanol (EtOH), then sketched, dissected and described under low power microscopy in the author's usual style. Small tissue samples were taken for genomic DNA extraction, PCR and COI 'barcode' sequencing (methods similar to those given in http://ibol.org) with results (in Appendix I) subjected to BLAST nucleotide analyses and searches of DNA barcode sequences (http://www.blast.ncbi.nlm.nih.gov/BLAST.cgi). After verification, these new data will be submitted and registered on GenBank (http://www.ncbi.nlm.nih.gov/ genbank/).

Classification follows Blakemore (2000c) at family level and Blakemore (2002; 2008; 2010a; 2010b) at genus and species levels. Specimens are deposited with acces- 

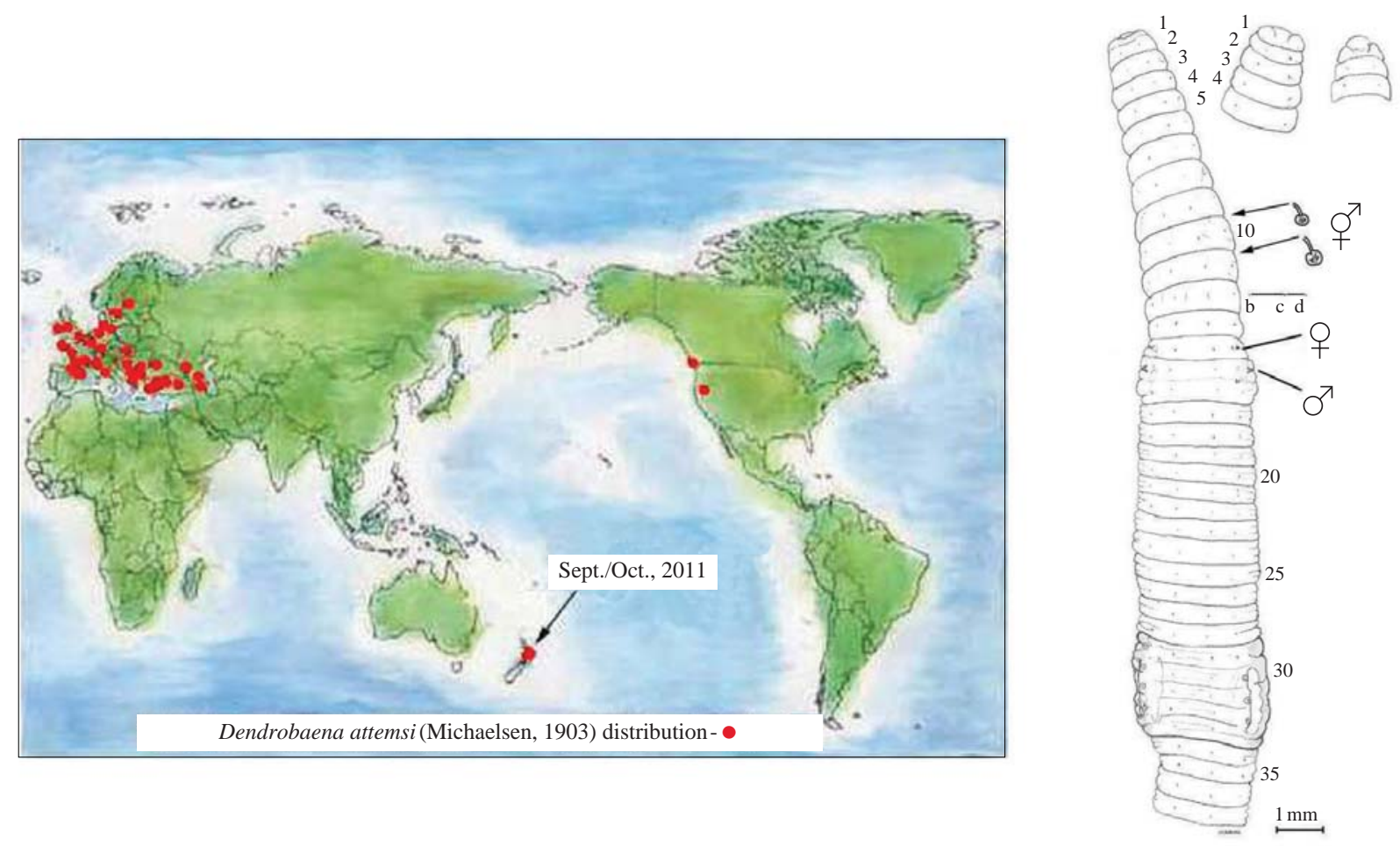

Fig. 1. Dendrobaena attemsi (Michaelsen, 1903) (NZ specimen AMNZ 2569) and its known distribution (full details in Blakemore, 2010b).

sion numbers prefixed AMNZxx in Auckland Museum (Tāmaki Paenga Hira) and W.0yy in Te Papa Tongarewa, Wellington or RB.95.zz in ANIC, Canberra (http://www. annelida.net/earthworm/Australasian\%20Earthworms/ Register.xls).

Discussion is confined to remarks accompanying species descriptions and mtDNA molecular analyses. Abbreviations are: coll.-collector, dps-dorsal pores, nps-nephropores; rhs and lhs-right- and left-hand-side, syn.-synonym, TP-tubercula pubertatis.

Appendix I presents raw COI gene barcode data, some with preliminary interpretation.

Appendix II provides an updated checklist of all known New Zealand earthworms, with a few species newly reallocated as part of routine taxonomic 'housekeeping'.

\section{Taxonomic Results}

\section{Earthworm surveys}

From a few dozen specimens unearthed, 18 or so earthworm taxa were identified, nearly half of which were new species or new records: Two were new NZ natives and new records were for three Megascolecidae Rosa, 1891 sensu Blakemore, 2000 in genus Anisochaeta Beddard, 1890 and three lumbricids, as detailed below. Other species simultaneously recovered will be treated elsewhere in due course.

Locations of species were:

1/. Mt Wellington in Auckland (ca. $36^{\circ} 55^{\prime} 00^{\prime \prime} \mathrm{S} 174^{\circ}$ $49^{\prime} 00^{\prime \prime} \mathrm{E}, 125 \mathrm{~m}$ ), a scoria cone with its flanks given over to cattle pasture (coll. RJB, $14^{\text {th }}$ Oct., 2011), earthworms (AMNZ 5264-5269) were identified as: Lumbricus terrestris Linnaeus, 1758; Aporrectodea caliginosa (Savigny, 1826); Aporrectodea tuberculata (Eisen, 1874); Lumbricus rubellus Hoffmeister, 1843; Octolasion cyaneum (Savigny, 1826), a new NZ record of Dendrobaena attemsi (Michaelsen, 1903) (Fig. 1), plus exotic Anisochaeta kiwi sp. nov. (AMNZ 5270-5272) (remarkably, these latter two species found also at Golden Springs noted below). Although the actual crater was impenetrable due to red scoria boulders, on the outer grassy slopes and especially under rocks and logs were many unidentified Enchytraeidae and several flatworm planarian predators some a deep royal-blue colour. Moreover, the worm burrows were like 'subterranean highways' for Collembola and Protura and/or Diplura. This biodiversity, plus all the attendant predators and parasites (e.g. Yeates et al., 1998), attesting to the ecological health and food-web complexities of this small habitat that was but briefly surveyed. The seven earthworm taxa, collected in about an hour, show possible pasture assemblage diversity higher than the two or three species that most reports claim, as was noted by Lee (1985). Nevertheless, Sch- 

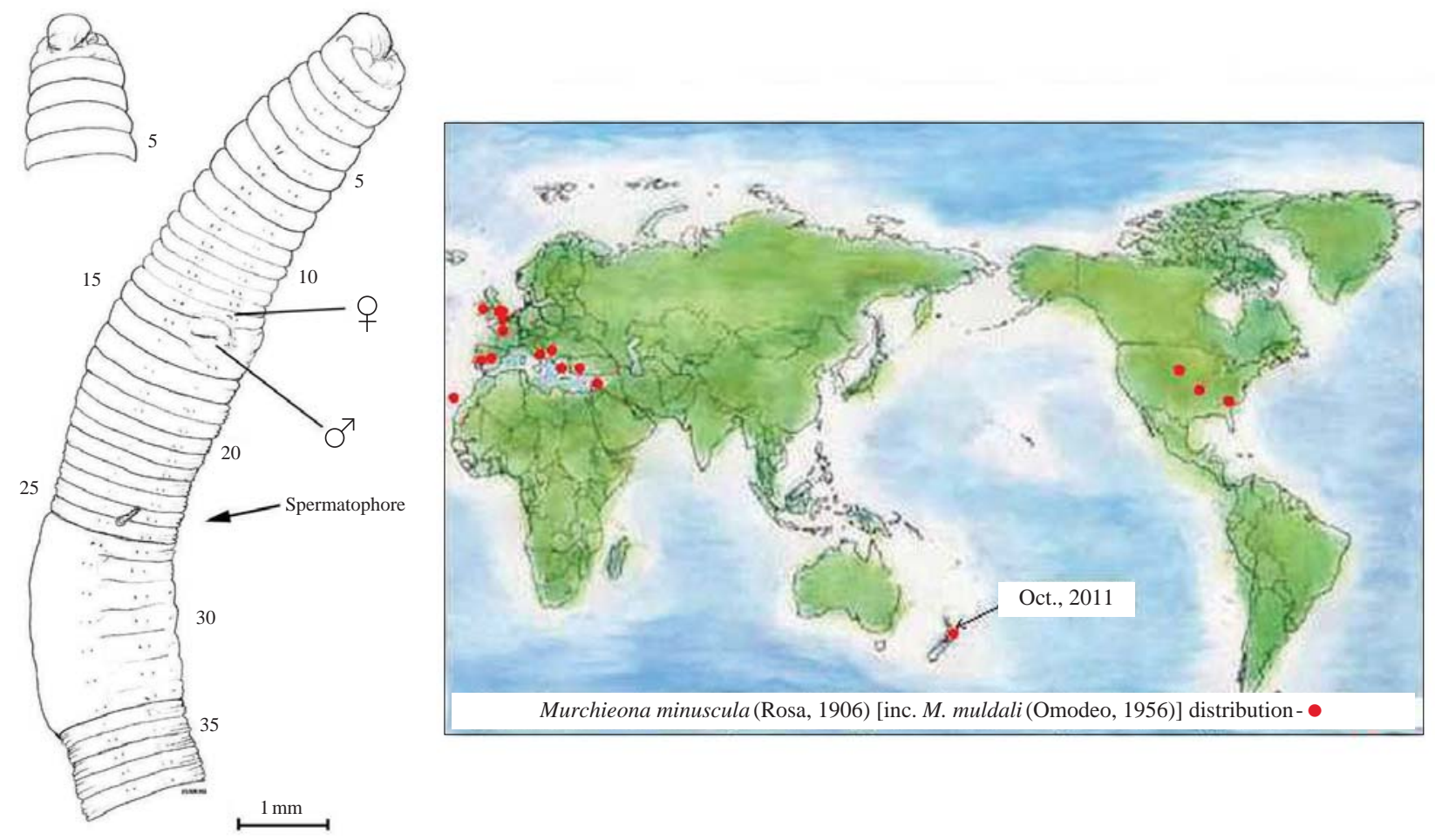

Fig. 2. Murchieona minuscula (Rosa, 1906) muldali (Omodeo, 1956) (NZ specimen AMNZ 2579) and its known distribution (full details in Blakemore, 2010b).

marda's Megascolides orthostichon was not rediscovered.

2/. Golden Springs Holiday Park, Mihi-Reporoa near Taupo (coll. RJB, $11^{\text {th }}$ Sept., 2011) earthworms were identified as lumbricids: Aporrectodea caliginosa speciescomplex $s$. Blakemore (2002) (macerated specimens not kept); Dendrobaena attemsi (AMNZ 5258)-as found at Mt Wellington-a new record for New Zealand/Australasia (cf. its previous false "Downunder" records noted by Blakemore, 1999); Dendrodrilus rubidus tenuis (Eisen, 1874) (AMNZ 5259); and Octolasion cyaneum (specimens not kept); plus exotic Anisochaeta kiwi mihi subsp. nov. (AMNZ 5260-5261)-this a newly recorded introduction as yet unknown in its Australian homeland, that is described below.

3/. Wairakei Geothermal Station at Taupo $\left(38^{\circ} 37^{\prime} 37^{\prime \prime}\right.$ $\mathrm{S} 176^{\circ} 06^{\prime} 19^{\prime \prime} \mathrm{E}$ ) near to original well WK44/0 (coll. RJB, $13^{\text {th }}$ Sept., 2011) earthworms found were: Anisochaeta macleayi (Fletcher, 1889) (AMNZ 5262-5263)-a new record for NZ of a known Australian species; Aporrectodea trapezoides (Dugès, 1828) (AMNZ 5264)-the same as those found in Australia and Asia and different in appearance to Mokai morphs mentioned later; and a specimen of Octolasion cyaneum that was released after field identification.

4/. Mokai near Taupo had Eisenia fetida (Savigny, 1826) confirmed (pers. obs. $15^{\text {th }}$ Sept., 2011) from a ver- micomposting operation of Tuaropaki geothermal glasshouse facility; (this species also observed in a garden at Grafton Halls, Auckland). In a later Mokai survey, morphs of "Aporrectodea caliginosa species-complex" and a darker morph initially labeled "A. cf. trapezoides" were shown by mtDNA results to be A. tuberculata and A. caliginosa, respectively (AMNZ 5276, AMNZ 52735274), the latter predominant in a cattle paddock (coll. $\mathrm{RJB}+\mathrm{BW}, 19-20^{\text {th }}$ Oct., 2011) with mean population estimated at 7.16 million worms ha ${ }^{-2}$ and 1.6 tha $^{-2}$ (detailed in Blakemore, 2011a).

5/. The Domain en route to the Museum, near the stream outlet that was Auckland's original water supply (coll. RJB, $27^{\text {th }}$ Oct., 2011) sourced Murchieona muldali (Omodeo, 1956) morph or subspecies of Murchieona minuscula (Rosa, 1906) (AMNZ 5279) (Fig. 2)-yet another new record for New Zealand of an introduced European lumbricid. Many authors combine these as parthenogenetic morphs, yet Csuzdi \& Pavlícek (2002) advocate maintaining both species and discuss their taxonomy and distributions.

6/. Mangamingi Station at Mihi, near Taupo, lumbricids $L$. rubellus and $L$. terrestris plus two new natives species as described below.

7/. Waiotapu-Ngapouri (coll. RJB, 28 ${ }^{\text {th }}$ Nov. 2011) yielded Lumbricus rubellus, Amynthas corticis (Kinberg, 1867) species-complex s. Blakemore, 2002 (AMNZ 


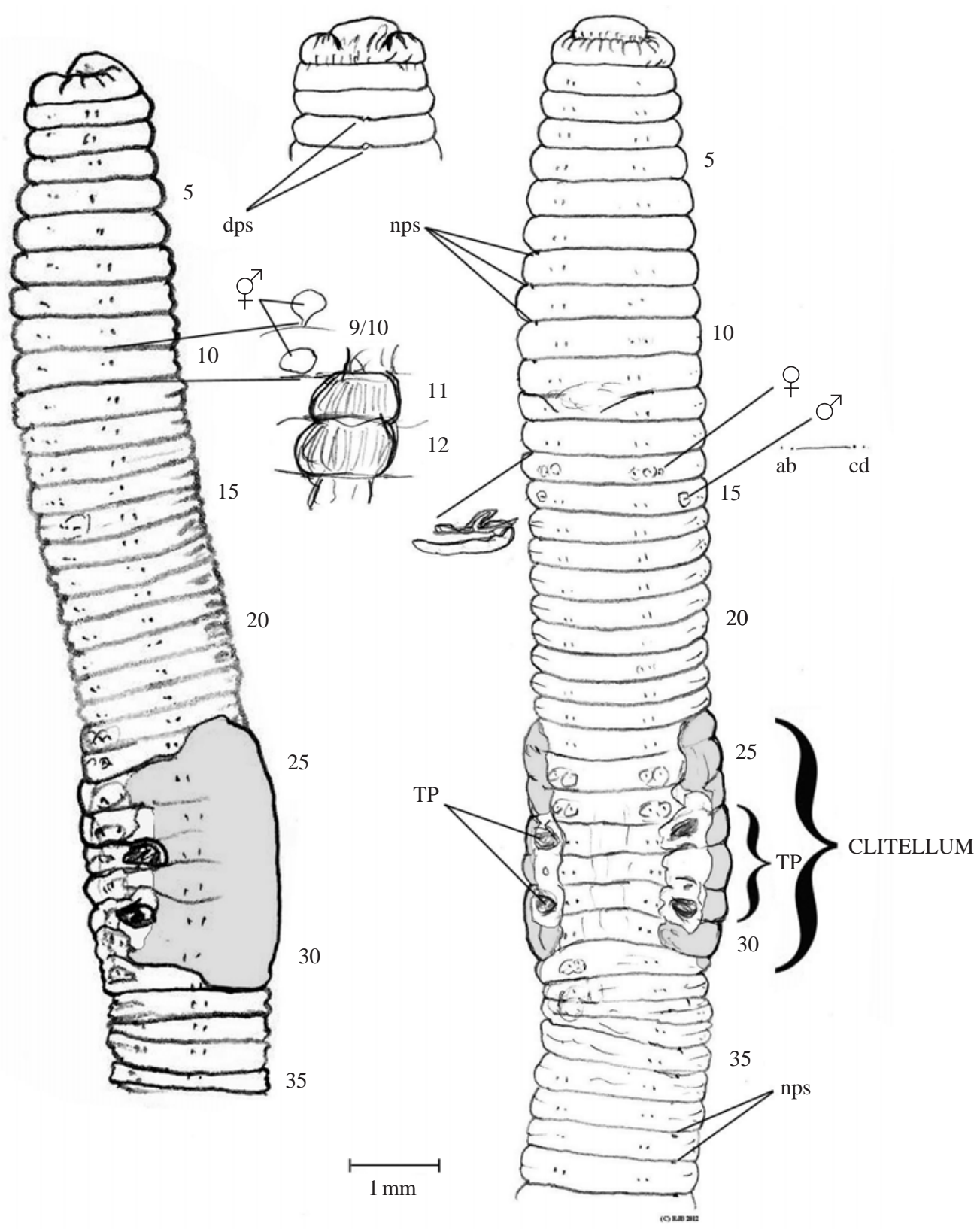

Fig. 3. Eisenia japonica (Michaelsen, 1892) Aarataki specimen (AMNZ86031) from Waiotapu-Ngapouri site, NZ. Figure shows its lateral and ventral habitus aspects, with dorsal view of prostomium, spermathecae exiting in setal c lines, calciferous glands and a nephridium in situ, plus actual setal ratios.

86030 and AMNZ86033-a total of three specimens-see mtDNA in Appendix I) and Eisenia japonica (Michaelsen, 1892) (AMNZ86031) that is a further new Australasian record for an Asian lumbricid, as noted in its following account.

Taxonomy of new Eisenia japonica sub-spp.

Family LUMBRICIDAE Rafinesque-Schmaltz, 1815 Genus Eisenia Malm, 1877

\section{Eisenia japonica japonica (Michaelsen, 1892)}

[Fig. 3]

This taxon and its sub-species are reviewed in detail by Blakemore $(2003,2010 b)$ and in Blakemore \& Grygier (2011) based on German types and fresh Japanese material. The NZ specimen is described below for comparison.

Distribution. Possibly endemic to Japan (Hokkaido to Kyushu) and Korea, or to China and Siberia where it is 
listed in a Red Data Book of the Russian Federation from Sakhalin Island; introduced to Taiwan, there is a single record from Germany plus an unconfirmed report from Slovakia. No previous records are from Australasia.

Material examined. Specimen (AMNZ86031) from Waiotapu-Ngapouri, immediately behind the Arataki Honey processing yards in a midgy, waterlogged paddock $\left(\mathrm{S} 38^{\circ}\right.$ 20.447 E176²1.654; Grid ref. ca. NZtopo50 BF37934511, $400 \mathrm{~m}$ AMSL, from www.waikatoregion.gov.nz/PageFiles/ 20544/1.3Waiotapu.pdf: pg 108 with vegetation data) adjacent to a geothermal pool (soil pH 4.7, 23.5 ${ }^{\circ} \mathrm{C}$ ). Collector, RJB, $28^{\text {th }}$ Nov. 2011. Sample also contains an unidentified immature lumbricid (AMNZ86032) for which DNA is pending.

Description of NZ specimen. Body circular in section, $41 \mathrm{~mm}$ long with 121 segments (11/12 and 33-34 slightly irregular/damaged); unpigmented and transparent in posterior and ventrum, pink anteriorly and puce dorsally, clitellum buff, saddle-shaped in $1 / 223,24-31$ with TPs prominent on $27 \& 29$. Prostomium open epilobous. Setae lumbricine with ventrally tumidity around $a b$ on $14,21,25,26$, and slightly in 29-31. Dorsal pores minute in $3 / 4$, open from $4 / 5$. Nephropores in mid-bc in 8-12, 15-16rhs, 19-21 and above $d$ in other segments (especially obvious on clitellum). Spermathecae in 9/10/11 in setal c lines. Female pores on 14 lateral to b setae. Male pores small on 15 in mid-bc.

Internally, septa are not especially thickened. Commissurals are in 7 (and 8?), hearts in (8),9-10 but not clearly found in 11. Holandric with testis iridescent and free in $10 \& 11$, seminal vesicles small in 9 and 10 and larger in 12. Spermathecae are lateral in $9 \& 10$. Ovaries and funnels are in 13; no ovisacs noted in 14. Annular calciferous glands are in $11 \& 12$. The intestinal crop is in 1516 , the muscular gizzard occupies 17-18 with a low typhlosole developing soon after. Nephridia are vesiculate, the bladders sausage shaped.

mtDNA results. Unfortunately, results for syntypes failed and the Arataki sample WM6 was contaminated (resamples as WO8 and WO9 also failed), but data for Japanese topotypic and other specimens of E. japonica from National Museum of Nature \& Science, Tokyo (hereafter NSMT) An-415 \& An-417 (detailed in http://ibol.org) are given in Appendix I.

Remarks. Albeit manifestly different in other regards, the markings when prominent in $27 \& 29$ in E. japonica sub-species are reminiscent to those in $28 \& 30$ in Allolobophora cupulifera Tétry, 1937. The Arataki specimen from NZ complies with previous descriptions of $A$. japonica japonica (its DNA sample was contaminated or mixed up).

A distinct specimen (NSMT An-415) from Hodogaya shows molecular similarity no better than $93 \%$ with (NSMT An-417) topotype from Enoshima, confirming my initial reservation of its inclusion and indicating, moreover, that speciation and divergence has already occurred within native (or introduced?) populations in Japan. The opportunity is here taken to formally name and briefly describe this specimen, comparing it to the Arataki specimen of E. japonica and to E. anzac Blakemore, 2011, as follows.

\section{Eisenia japonica hiramoto sub-sp. nov.}

[Fig. 4]

Eisenia japonica (part.): Blakemore \& Grygier, 2011: 270, fig. 4.

Material examined. Holotype, H, (Tokyo NSMT An415) from under Eucalyptus sp. gum tree in park next to the Commonwealth War Graves Commission Cemetery

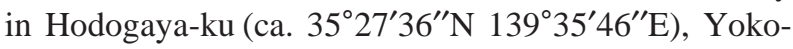
hama-shi, Kanagawa-ken, Japan. Collected by RJB and Yuko Hiramoto, Anzac Day, 25 ${ }^{\text {th }}$ April, 2010.

Etymology. In honour of its co-collector's family name. Diagnosis. Defined on its clitellum in 24-31 and TP in $27 \& 29$ as in E. japonica japonica and other sub-species, plus a pair of distinctive setal tumescences around $\mathrm{ab}$ of segment 25 . Unique mtDNA COI barcode sequence definitive (presented in Appendix I).

mtDNA results. BLASTn of Holotype An-415 shows alignment no better than $93 \%$ (Identities =414/445) with Enoshima E. japonica topotype An-417. megaBLAST similarity is $<84 \%$ with some pre-existing European lumbricid vouchers sequences on GenBank.

Remarks. Newly named E. japonica hiramoto appears to differ from other sub-species morphologically (as noted above also cf. Figs. $3 \& 4$ ) only in its pronounced markings found around setae ab in segment 25 while lacking those that typically occur around ventral setae on segments 21 and/or 22. Its recently-available COI barcode data is unequivocal. Possibly it merits specific status as indicated by divergence of its COI gene, but superficial similarity to E. japonica is compelling and, moreover, it may be endemic.

Found simultaneously was Japanese Eisenia anzac Blakemore, 2011 (cf. its mtDNA COI data in Appendix I) and an Amynthas sp. nov. to be detailed elsewhere.

Taxonomy of new and of known exotic Anisochaeta (sub-)spp.

\section{Family MEGASCOLECIDAE Rosa, 1891 sensu Blakemore, 2000 \\ Genus Anisochaeta Beddard 1890}

Pertinent background information is that the Australian genus Anisochaeta Beddard, 1890 was for a long time overlooked, mostly subsumed in Spenceriella Michael- 


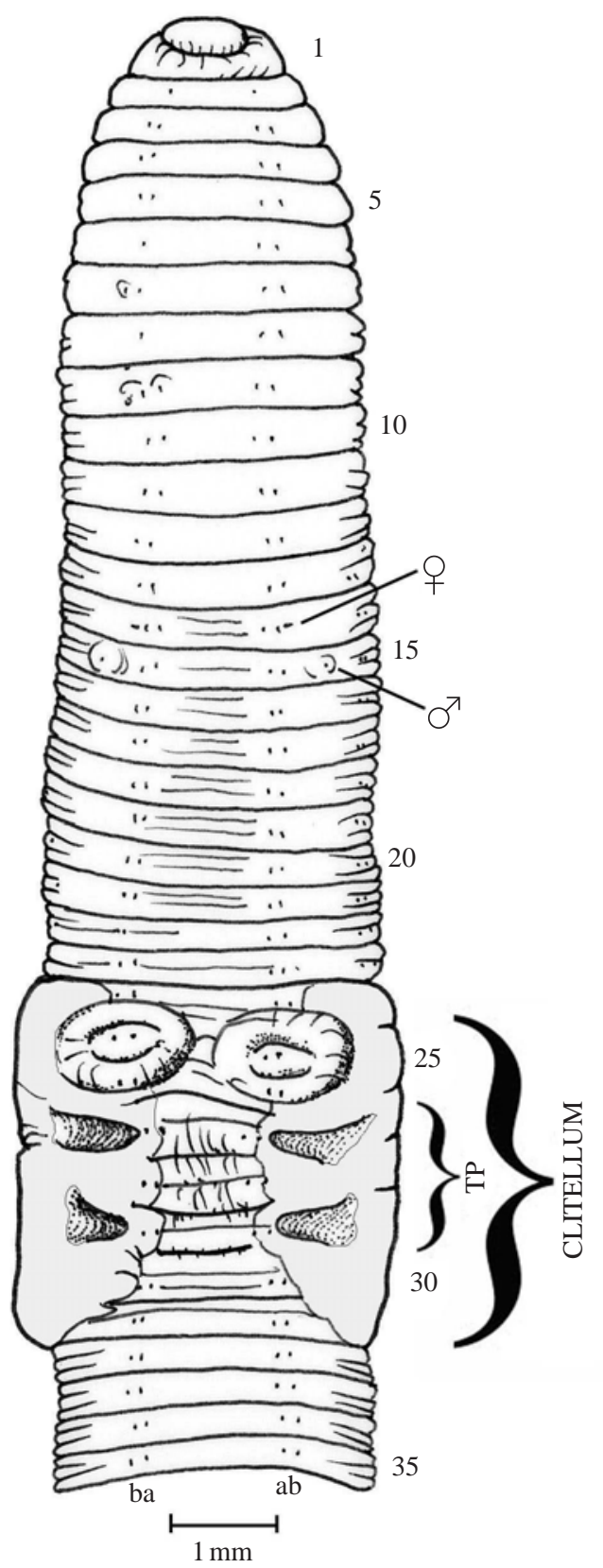

Fig. 4. Eisenia japonica hiramoto Blakemore, sub-sp. nov. Holotype (Tokyo An-415) from near Commonwealth Graves Cemetery, Hodogaya-ku, Yokohama, Japan.

sen, 1907 while accruing a few other genera, until formally restored by Blakemore (1997). Megascolex Templeton, 1872 (objective synonym Pleurochaeta Beddard, 1883) is a similar genus restricted to Indian species. Gates' (1965) synonymy of what was then Megascolex laingii Benham, 1903 in prior Perichaeta newcombei Beddard, 1887, now both in Anisochaeta, was questioned then revived by Blakemore (1994: 515; 1997: 1842) despite the original species description being based on fragments lacking clitella and with types now lost (Fig. 5). Initially only reported from Norfolk Island, a part of the Commonwealth of Australia, A. laingii was retained on NZ lists due to later reports (e.g. Gates, 1965) from Hamilton and from Raoul Island, albeit these are probable misidentifications especially in view of the number of other Anisochaeta species now known hereabouts (vide infra). Sometimes yet misplaced in genus Megascolex Templeton, 1844 it is, moreover, most likely on present knowledge that Anisochaeta laingii is a species introduced from the Australian mainland to its type-locality by (recent?) human activity, hence it is neither a Norfolk Island neoendemic (sensu Blakemore, 1999) nor a direct translocation from New Zealand proper.

Anisochaeta laingii (Benham, 1903) (Fig. 5) from Norfolk Island (Australia) and Australian Anisochaeta macleayi (Fletcher, 1889) from Wairakei, NZ are comparable to Anisochaeta minor (Spencer, 1900) from Queensland, Australia-see Blakemore (1994; 1997; 2000a; 2010b) and Blakemore \& Elton (1994). These references show that representatives of native genus Anisochaeta are particularly widespread in Australia and appear resilient to agricultural cultivation/habitat disturbance (e.g. specimens lodged and registered at ANIC, Canberra, as noted in Introduction). Anisochaeta sp were found in abundance by the author in January, 2011 in the grounds of New South Wales (NSW) Department of Environment \& Climate Change facility in Sydney suburb of Lidcombe, further indication they would be suitable native monitorspecies for eco-toxological studies.

\section{Anisochaeta kiwi sp. nov.}

[Fig. 6]

Material Examined. Holotype, H(AMNZ 5270), a complete specimen, sketched and dissected, plus paratype P1 (AMNZ 5271) also sketched and dissected, paratypes P2-P16 (AMNZ 5272) 14 mostly mature specimens, including two juveniles and an anterior "head" regenerate specimen that lacks markings (regressed?). From SW face of Mt Wellington, Auckland (ca. $36^{\circ} 892990 \mathrm{~S} 174^{\circ}$ 845545E, 120 m). Collector RJB, 14 ${ }^{\text {th }}$ Oct., 2011.

Etymology. Nominal taxon after "Kiwi", the colloquial name for New Zealanders.

Diagnosis. Anisochaeta having spermathecal pores in bc lines in 7/8/9; markings absent from anterior but variously near male pores, strong gizzard in 5, last hearts in 12 and oesophagus dilated in 13 ; ovisacs typically present in 14. COI barcode in Appendix I.

Behaviour. Vigorous and rapid escape to disturbance (more so than lumbricids).

Length. Holotype (H) (AMNZ 5270) ca. $90 \mathrm{~mm}$; mature paratypes $85-95 \mathrm{~mm}$ Widths. ca. 1-1.5 mm. Body/segments. $(\mathrm{H}) 95$; body tapers and flattens to tail end. 

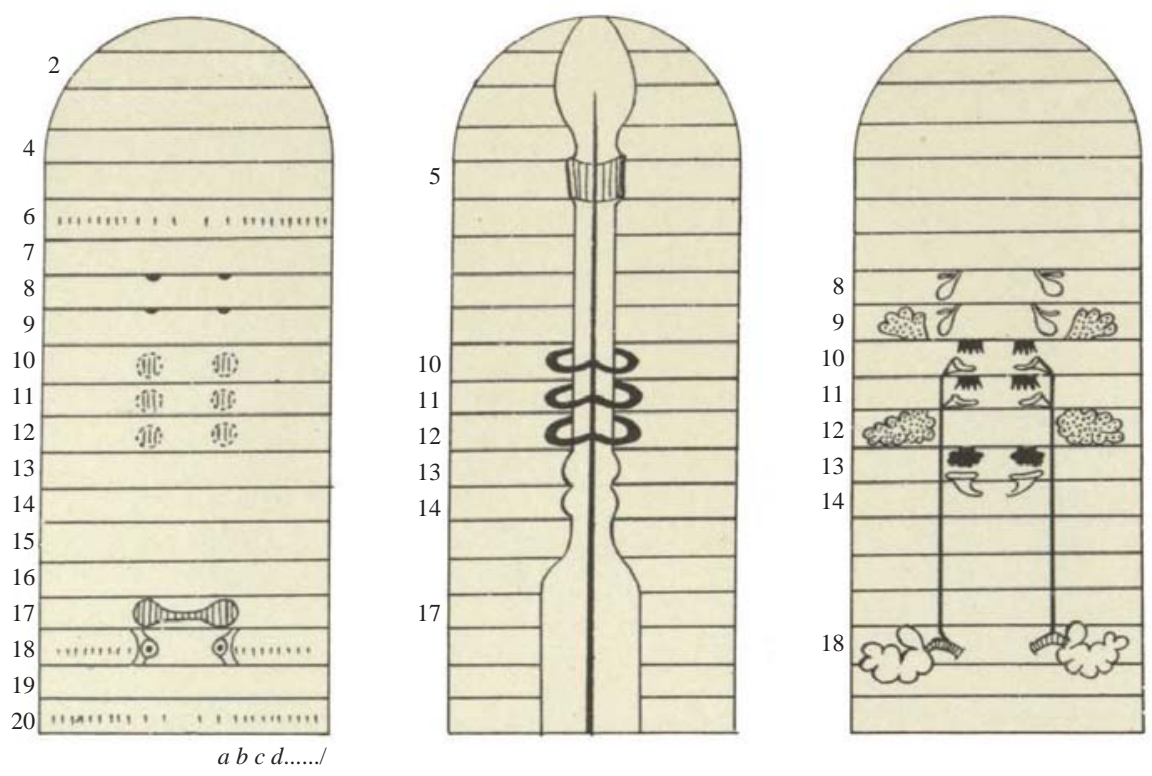

Fig. 5. Anisochaeta laingii (Benham, 1903) from Norfolk Island (Australia) the only previous Anisochaeta questionably reported from NZ. Its markings in segments 10-12 and 17 differ, but internal organization is somewhat similar to the new Anisochaeta spp. herein (After Benham's original with copy permission from Royal Society NZ; Oct., 2011).

Colour. A brick brown-red or puce dorsum with iridescent sheen, with a darker mid-dorsal line; pale ventrally; clitella buff.

Prostomium. Open epilobous; ventrally cleft peristomia.

First dorsal pore. From 5/6.

Setae. Perichaetine with $28-36$ per segment increasing further posteriorly.

Nephropores. Not found (meroic).

Clitellum. Annular 1/213-16, sometimes slightly encroaching into 17 (e.g. P1).

Male pores. Superficial and small eye-shaped on low papillae insunk on 18 in setal $b$ lines.

Female pores. Single mid-ventral on 14.

Spermathecal pores. $7 / 8$ and $8 / 9$ in line with setal interval bc.

Genital markings. Holotype $(\mathrm{H})$ has small disc-like markings paired posteriorly in 17 and anteriorly in 19 lining up with the male pores; its P1 paratype has them narrower in 17 and in 17/18, rather than 19, where they are wider; other mature paratypes (AMNZ 5272) have various combinations including marking on 16 in some or near $17 / 18$ and $18 / 19$, the last location more usual; one specimen with no marking was also an anterior regenerate.

Septa. None especially thickened.

Blood vessels. Dorsal vessel single, connects to supraoesophageal as seen in $9-1 / 214$.

Hearts. Commissurals in 7-9, hearts in 10-12 from supraoesophageal vessel.
Gizzard. Compact and muscular in 5 preceded in 4 by pharyngeal mass.

Calciferous glands. Oesophagus only slightly dilated in 13; valvular in 15 .

Intestine. Origin in 16; caeca absent; typhlosole not found. Nephridia. Meroic, with large tufted peptonephridia anteriorly in 4.

Testis/seminal vesicles. Holandric, paired testis in 10 and 11 free but invested in mucus; seminal vesicles paired, racemose in 9 and larger in 12.

Ovaries. In 13; ovisacs in 14.

Prostates and penial setae. Tubuloracemose gland with short duct; penial setae not found but their presence anticipated, possibly as small setae implicated with the male pores, since setae a are most often occluded or displaced on 18.

Spermathecae. In 8 and 9 with globular ampullae each with a shorter, curved diverticulum not especially dilated terminally, opening by its own duct into short main duct.

Gut contents. Organic mixed soil.

mtDNA results. BLASTn analysis of COI results (Appendix I) shows that $A$. kiwi holotype (H) and paratype (P1) are $100 \%$ identical despite their apparent differences in genital markings (cf. A. macleayi outlined below). mega BLAST has no close matches-the nearest at $85 \%$ max identity is an unidentified GenBank "Megascolecidae sp." from the Philippines.

Remarks. A species introduced from Australia, where its origin and nearest relations may be sought (possibly 


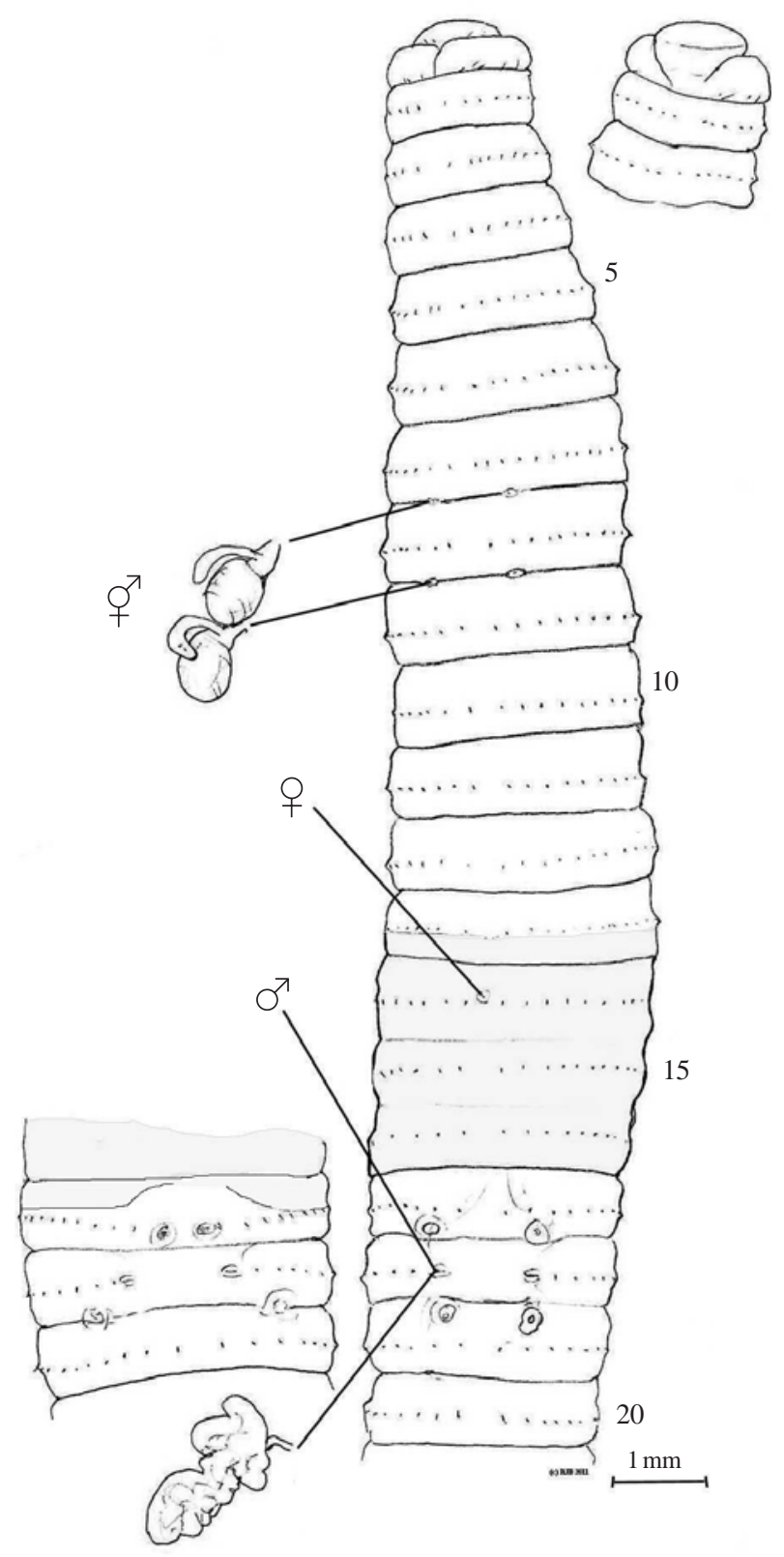

Fig. 6. Anisochaeta kiwi Blakemore sp. nov. Holotype (AMNZ 5270) from Mt Wellington. Ventral aspect with dorsal view of epilobous prostomium, spermathecae and $18 \mathrm{lhs}$ prostate in situ; male field of Paratype P1 (AMNZ 5271) shown for comparison (also cf. Fig. 7). Superficially differing, mtDNA COI agrees $100 \%$ for $\mathrm{H}$ and P1, i.e., same species (see Appendix I).

with different provenances of its sub-species, A. kiwi mihi below). It differs from Anisochaeta minor (Spencer, 1900) from Queensland which is usually just 50-60 mm long, with paired female pores (always?), and often distinctive genital markings paired in 10,11 (and 16 or 17) and 20 that, although varying between its specimens, are the usual locations. Distinction of the current species from the rather inadequate description of Anisochaeta laingii

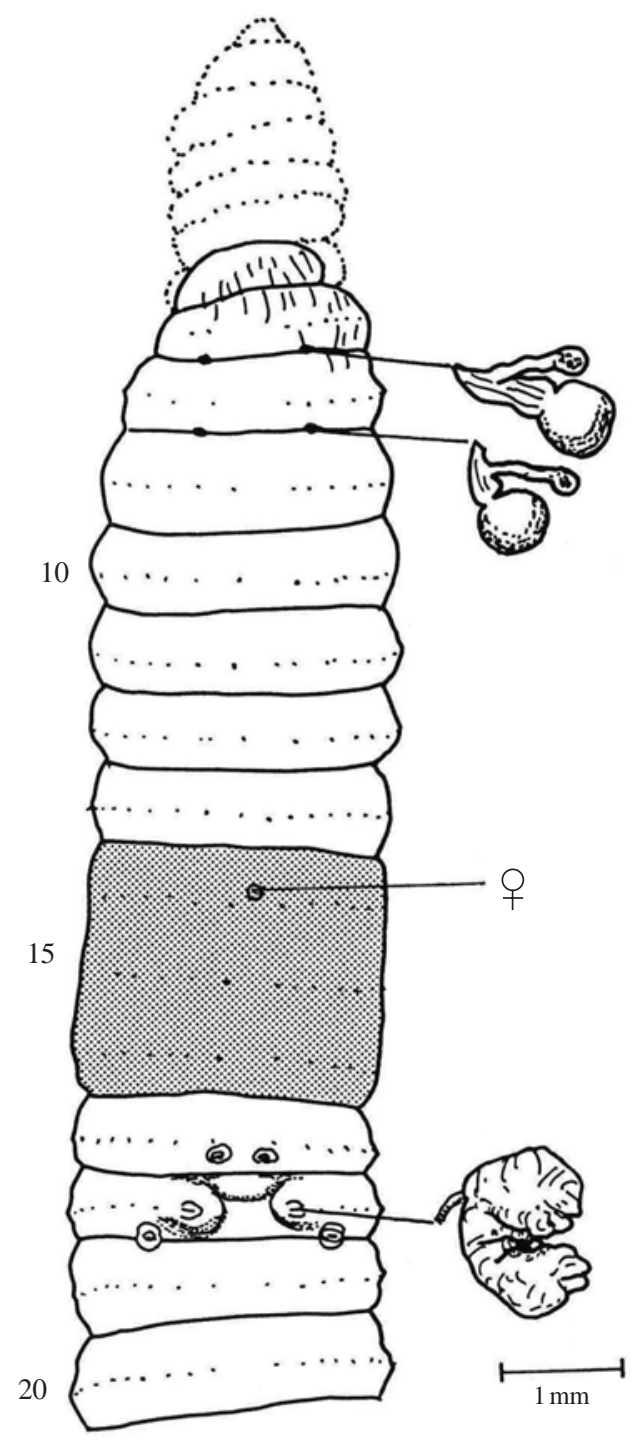

Fig. 7. "Spenceriella decapita" unpublished Queensland taxon from Blakemore (1994). This damaged specimen (ANIC RB.95. 5.19) is remarkably similar to Mt Wellington paratypes, especially P1, of A. kiwi kiwi (Fig. 6).

(Benham, 1903) (Fig. 5) is mainly due to its lack of markings on 10-12 and the characteristically con-joined pair in 17; instead, A. kiwi most consistently displays a pair of small papillae in or near $18 / 19$ below its male pores and other combinations as noted.

Anisochaeta kiwi is somewhat reminiscent of A. sebastiani (Blakemore, 1997) that is widely distributed in Eastern Australia and Tasmania, but which has a vestigial gizzard and typically lacks genital markings entirely. Remarkably, the current species-and especially specimen P1 from Mt Wellington (Fig. 6)-resemble almost exactly one described 20 yrs earlier under the provisional name "Spenceriella decapita" (Fig. 7) from the 80 or so species in a PhD Thesis (Blakemore, 1994). This specimen 
(ANIC RB.95.5.19-see www.annelida.net/earthworm/ Australian\%20Earthworms/Register.xls) was collected by C.H. Thompson, $24^{\text {th }}$ May, 1992 from a rural-residential garden at Brookfield, Brisbane, Queensland-the possible state of origin of the current stock. The only significant difference is that I recorded its last hearts as in segment 13. For that unpublished species, Blakemore (1994: 542) noted:

"The endemic genus Spenceriella [now=Anisochaeta $]$ has many unnamed and morphologically similar species, often differing intraspecifically [I meant to say "interspecifically'] in the distribution of genital markings. The damaged individual described here is insufficient for definite classification, but appears very similar in form to S. sebastianae and S. stephanie [eventually published as Anisochaeta sebastiani (Blakemore, 1997) and A. stephanieae (Blakemore, 1997)]."

\section{Anisochaeta kiwi mihi sub-sp. nov.}

[Fig. 8]

Material Examined. Holotype (AMNZ 5260), a single complete specimen, dissected, plus paratypes, P1-20 (AMNZ 5261) comprising 20 specimens, several posterior amputees, of various life stages; (one was abnormal with marking $17 / 18 \mathrm{lhs}$ but spermathecal pores in $6 / 7$ / 8/9 and spiraling segments around 14). From Golden Springs Holiday Park (GPS E2798840.N6298535 300 m) at Mihi-Reporoa in Broadlands district central North Island near Taupo $\left(38^{\circ} 37^{\prime} 1^{\prime \prime} \mathrm{S} .176^{\circ} 2^{\prime} 36^{\prime \prime} \mathrm{E}\right)$, beside pools of tepid creek $\left(33^{\circ} \mathrm{C}\right)$ feeding from local Golden Springs source that flows into the Waikato River via the Waiotapu Stream; the soil was slightly black and sulphurous (low $\mathrm{pH}$ ?) and the garden included exotic plants such as bamboo (Pseudosasa japonica?) as well as native trees (details: http://www.waikatoregion.govt.nz/PageFiles/20544/ 1.10Reporoa.pdf). Collector RJB, $11^{\text {th }}$ Sept., 2011.

Etymology. Mihi after district location of the sub-species with "mihi" meaning "to greet".

Diagnosis. Anisochaeta as for A. kiwi kiwi but with dorsal pores from $4 / 5$ and markings typically paired in 18/19, and rarely (in only one specimen with a rhs analogue) in $17 / 18$, i.e., not found in 17 or 19 as typically seen in $A$. kiwi kiwi, or markings completely absent. mtDNA COI barcodes in Appendix I help define this sub-species.

Behaviour. Rapid escape response with autotomy of tail, and ejection of yellow coelomic fluid through (anterior) dorsal pores-all typical prey defensive responses of a superficial, litter-dwelling species.

Length. Holotype (H) (AMNZ 5260) $88 \mathrm{~mm}$, paratypes 60-80 mm for complete specimens. Widths. ca. 1-1.5 mm. Body/segments. $(\mathrm{H})$ 98; body narrows and flattens to tail end that is often missing through autotomy/predation.
Colour. A brick brown-red dorsum with iridescent sheen, with a darker mid-dorsal line; pale ventrally; clitella buff. Prostomium. Open epilobous; ventrally cleft peristomia.

First dorsal pore. From 4/5.

Setae. Perichaetine with ca. 32 on segment 12.

Nephropores. Not found (meroic).

Clitellum. Annular, 1/2 13-16.

Male pores. Superficial and small eye-shaped on low papillae insunk on 18 in setal b lines.

Female pores. Single mid-ventral on 14.

Spermathecal pores. $7 / 8$ and $8 / 9$ in line with setal interval b or bc; an abnormal $A$. $k$. mihi paratype $65 \mathrm{~mm}$ long with markings in $18 / 19$ had an extra segment spiral at 14 and an additional spermathecal pore in $6 / 7 \mathrm{lhs}$ as well as those in $7 / 8 / 9$.

Genital markings. Markings are most often paired in or near $18 / 19$ wider than male pores, or markings may be unilateral in $17 / 18$ or $18 / 19$, or absent (e.g. in one paratype $80 \mathrm{~mm}$ long); one A. k. mihi paratype $75 \mathrm{~mm}$ long had marking unilateral in $17 / 18$ rhs and another pair anteriorly on 19 below male pores. Some variation is thus apparently permissible. No glands were found internally in position of these markings.

Septa. None especially thickened, 12/13/14 are slightly stronger but still translucent.

Blood vessels. Dorsal vessel single, connects to supraoesophageal in 9-1/214.

Hearts. Commissurals in 7-8, hearts in 9-12 from supraoesophageal vessel.

Gizzard. Compact and muscular in 5 preceded by pharyngeal mass to segment 4 .

Calciferous glands. Oesophagus only slightly dilated in 13; valvular in 15 .

Intestine. Origin in 16; caeca absent; typhlosole not found. Nephridia. Meroic, forests of tubules equatorially with large tufted peptonephridia anteriorly in 4 .

Testis/seminal vesicles. Holandric, paired testis in 10 and 11 free but invested in mucus; seminal vesicles paired, racemose in 9 and larger in 12 .

Ovaries. Large and conglomerated egg mass in 13 with funnels posteriorly; small pseudo-vesicles in 14 anteriorly may actually be elongate ovisacs.

Prostates and penial setae. Small, paired S-shaped tubuloracemose gland with short duct; penial setae not found.

Spermathecae. Two pairs in 8 and 9 with globular ampullae each with a medium, elongate diverticulum not especially dilated terminally, opening by its own duct into short main duct.

Gut contents. Dark organic matter from their rich soil/ litter habitats.

mtDNA results. BLASTn alignment shows A. kiwi mihi $\mathrm{H}$ vs. $A$. k. kiwi $\mathrm{H}$ Identities $=647 / 652(99 \%)$ with no gaps; unlike the $100 \%$ agreement of $A$. kiwi kiwi $\mathrm{H}$ and 

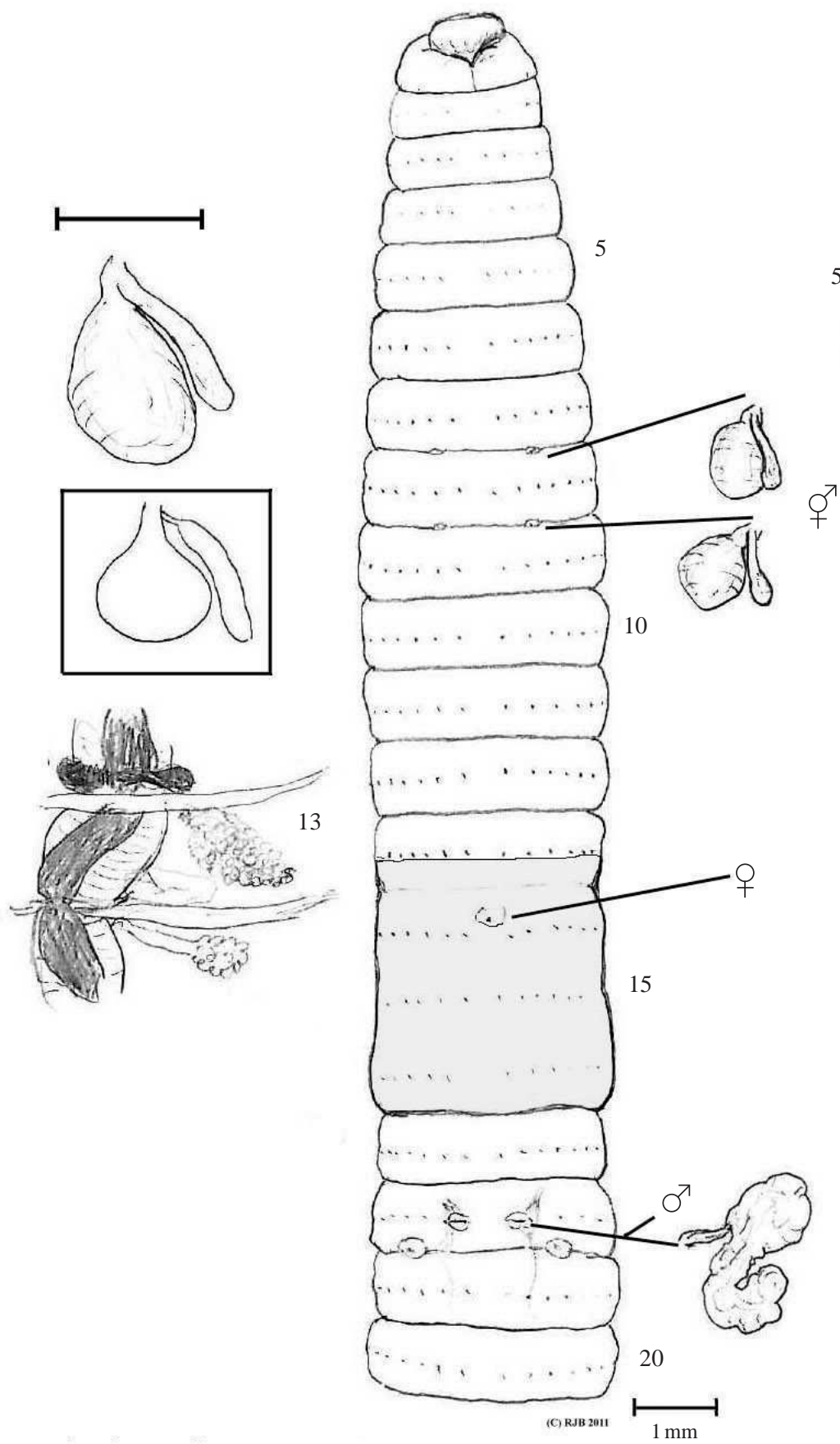

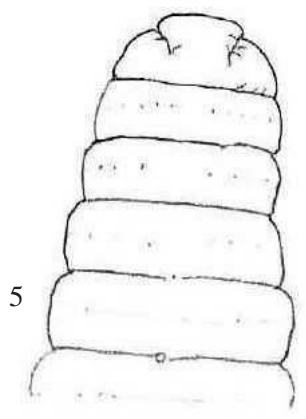

$\overbrace{}^{7}$

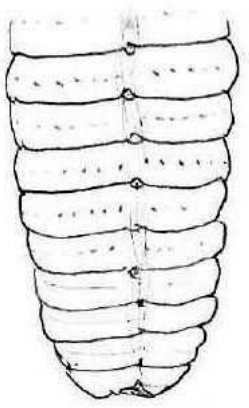

Fig. 8. Anisochaeta kiwi mihi Blakemore sub-sp. nov. Holotype (AMNZ 5260) from Golden Springs. Ventral aspect with dorsal view of epilobous prostomium, spermathecae, prostate and oesophageal gland in 13 in situ; plus tail end. [Boxed spermatheca (near enlargement of 8 rhs) is Anisochaeta laingii (Benham, 1903) from Lee(1959: fig. 305) for comparison].

$\mathrm{P} 1$ (and of A. macleayi S1 and S2).

Remarks. Acuity of COI gene appears to vary, at least for this genus, with fine intraspecific concordance, but wide interspecific gap (cf. A. macleayi differing by $86 \%$ ). Despite variation apparent in genital markings, Anisochaeta kiwi kiwi typically has markings in 17 and $\mathrm{A}$. kiwi mihi, which may have fewer markings overall, does not.
Possibly it merits combination, but mtDNA data gives tenuous molecular support to the conclusion from slight differences observed in makings and other morphological features that they represent discrete but potentially or actually interbreeding populations (i.e., sub-species) in their original homeland (s). Transportation to NZ (in plant pots?) is assumed to be recent (ca. $150 \mathrm{yrs}$ or less?), as for 
A. kiwi kiwi and it is interesting that no translocated populations are yet known intervening between Auckland and Taupo. Further survey is obviously required.

\section{Anisochaeta macleayi (Fletcher, 1889) [Fig. 9]}

This species is fully described by Blakemore (1994; 1997; 2000a; 2010b), and in Blakemore \& Elton (1994) but under its prior name, Spenceriella macleayi.

Distribution. Australia, these two specimens from Wairakei are a new record for NZ. Possible mechanisms for transportation are as discussed in Blakemore (1999, 2010b).

mtDNA. Whereas, BLASTn of Anisochaeta macleayi specimens AMNZ 5262 and 5263 (S1 \& S2) show $100 \%$ agreement, surprisingly they show similarity no better than $86 \%$ with congeneric A. kiwi. megaBLAST matches no better than $87 \%$ with Asian megascolecids.

Remarks. Further work is required to investigate the molecular boundaries of these taxa.

\section{Description of new native species}

Family ACANTHODRILIDAE Claus, 1880 sensu Blakemore, 2000

Genus Rhododrilus Beddard, 1889

\section{Rhododrilus mangamingi sp. nov.} [Fig. 10]

Material Examined. Holotype (H) AMNZ86028 (mature, sketched, dissected). From fenced remnant scrubland above and to NE of Te Kopia geothermal field features on sheep paddock at Mangamingi Station (ca. S38 5.535 E176 ${ }^{\circ}$ 12.996; Atiamuri region NZTM E1880782 N5742 165 AMSL $630 \mathrm{~m}$ pg. 223 of www.waikatoregion.govt. nz/PageFiles/20544/1.6TeKopia.pdf that provides ecological and vegetative data). Collected by RJB $28^{\text {th }}$ Nov., 2011. Fixed in $80 \%$ ethanol and small tissue sample removed for DNA analysis (WM5).

Etymology. After type locality.

Diagnosis. Acanthodrilid with microscolecine reduction of male and prostatic pores to 17 . Penial setae present. Muscular gizzard in 5. Spermathecal pores near b lines in 7/8/9. Markings on 19. Holoic nephridia avesiculate. mtDNA COI barcode as provided.

External characters. Body circular. Pale unpigmented; clitellum buff. Length $60 \mathrm{~mm}$ with 100 segments (broken in half during dissection). Prostomium epilobous. Setae lumbricine, evenly spaced. Clitellum annular, 1316. Neither dorsal pores nor nephropores found; however there are a few small mid-dorsal dots present after clitellum and minute perforations were detected in $\mathrm{c}$ lines in excised cuticle. Spermathecal pores near b lines in 7/8 and 8/9. Female pores on 14 above setae a. Male and prostatic pores combined at ab on 17; ab setae replaced with penial setae. Genital markings as faint indistinct pads in 19 posterior to ab setae (no glands internally). Setae ab in 18 and 19 appear unmodified.

Internal morphology. Septa all thin. Gizzard large in 5. Dorsal blood vessel single. The last pair of hearts detected in 12. Nephridia holoic, avesiculate in c lines throughout. Spermathecae in 8 and 9 each a spherical ampulla on short duct with a thumb-like diverticulum. Testes flat and iridescent in 10 and 11. Seminal vesicles large, racemose posteriorly in 9 and anteriorly in 11 and 12. Small pseudo-vesicles on posterior of $12 / 13$ and 13/14. Ovaries in 13 with several egg strings. Prostates tubular in 17 with a flaccid duct and long penial setae. Oesophagus not noticeably modified, with intestinal origin somewhat indeterminate after 16 (possibly in 17). Intestinal typhlosole absent. Gut contains fine soil (selective topsoil dweller rather than detritivore).

Ecology. Dug from loose soil under scrub near paddock fenceline with Lumbricus rubellus, L. terrestris (specimens not kept) and with Deinodrilus orcus sp. nov. nearby.

mtDNA results. megaBLAST match no closer than $84 \%$ max identity with various worms, i.e., nothing similar yet sequenced on GenBank.

Remarks. Rhododrilus is one of the larger genera with 30 New Zealand members (Lee, 1952a; 1959; 1962). The present species lacks dorsal pores (not mentioned by Lee) and has minute nephropores presumed to exit in setal c lines where avesiculate nephridia attach. Vesiculate Rhododrilus benhami Lee, 1952 is superficially similar with faint markings in 19 , but it has a tanylobous prostomium and spermathecal pores in setal a lines. Especially similar avesiculate species are Rhododrilus aquaticus Lee, 1959 from Caswell Sound in the SW Fiordland that is smaller $(30-40 \mathrm{~mm})$ with male pores at the end of a transverse ridge, amongst other differences, or $R$. cockaynei Benham, 1905 from Auckland, Campbell and Snares Islands that has a saddle-shaped clitellum and spermathecal pores at anterior margins of 8 and 9 (or 7, 8 and 9). Species with spermathecal pores in $7 / 8 / 9$ and annular clitella in 13-16,17 are $R$. huttoni (Benham, 1901) and $R$. dobsoni Lee, 1959 that also lack nephridial vesicles but both have prostatic pores in setal a lines; while vesiculate R. microgaster Lee, 1959 and R. papaensis Lee, 1952 additionally have reproductive pores that are mid-ventral or in ab lines, respectively. All four latter species also have different seminal vesicle arrangements.

The long, thin penial setae of the current species are distinctive, but their minutae are purposefully omitted for reasons cogently explained by Blakemore (2002; 2010a; 2010b), viz.: the microscopic details reported for these 


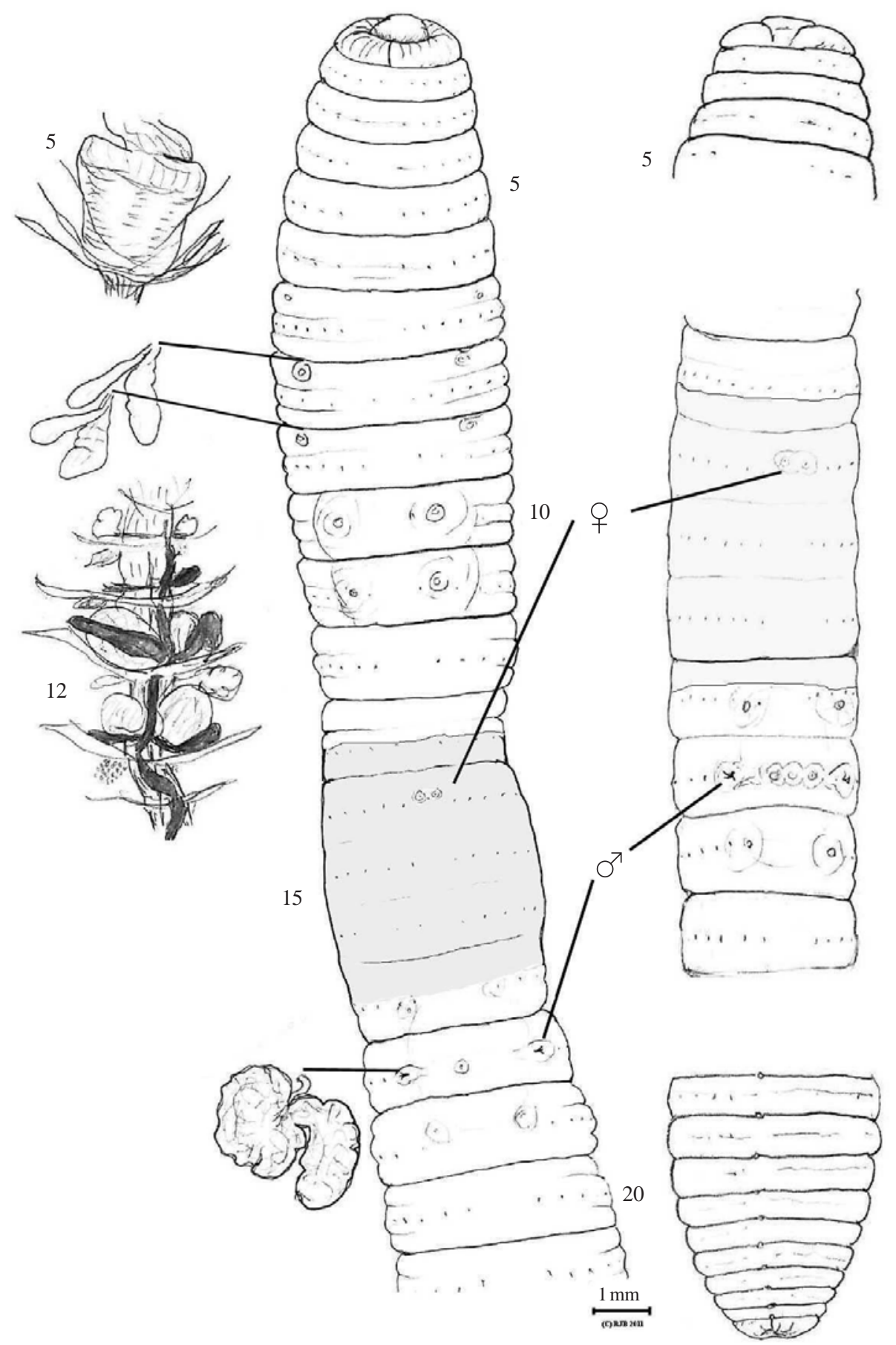

Fig. 9. Anisochaeta macleayi (Fletcher, 1889), Wairakei Steamfield near original Geothermal well WK 44/0 (central specimen "S1" AMNZ 5262, rhs specimen "S2" AMNZ 5263). Specimens differ slightly but mtDNA COIs $100 \%$ identical.

are of debatable value for some such taxa as they vary individually, even within a bundle, are damaged or worn by age and use, and may be similar if not the same in several species. For example, Lee (1962: 170) found details of penial setae of Rhododrilus minutus Beddard, 1889 to differ intraspecifically. And, as Gates (1972: 23) observed: "The systematic importance claimed for differ- ences of shape, sculpturing, and ornamentation in those kinds of setae in the classical system, may have been too great. Penial setae may show considerable intraspecific variation or may be similar if not the same in several species."

Moreover, even when present, the reliance on penial setal detail for specific characterization requires these be 


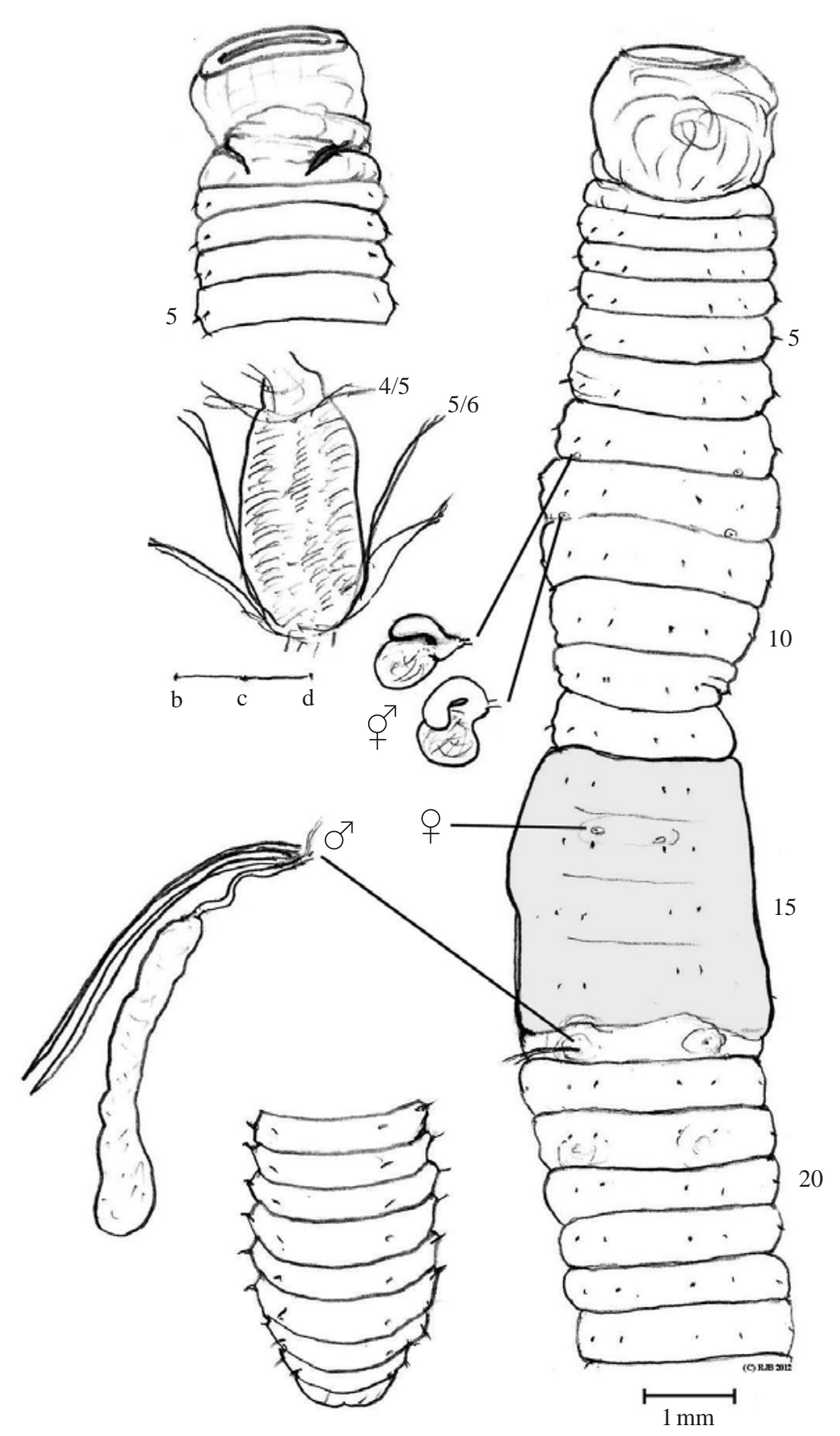

Fig. 10. Rhododrilus mangamingi Blakemore, sp. nov. Holotype AMNZ86028 showing dorsal views of prostomium (pharynx everted) and pygidium; ventral aspect of body with gizzard, spermathecae in $8 \mathrm{rhs} \& 9 \mathrm{rhs}$ and prostate in $17 \mathrm{lhs}$ with penial setae in situ, plus actual setal ratios in 9 rhs.

elucidated for all specimens under consideration (which is not always the case), and is impracticable for the majority of field workers who lack access to high-powered or scanning electrode microscopes (SEM) or for taxonomists pressed for time. Finally, their importance to determine specific affinities is rendered irrelevant when replaced by compelling DNA data (preferably from types), as used here.
Family OCTOCHAETIDAE Michaelsen, 1900 sensu Blakemore, 2000

Genus Deinodrilus Beddard, 1889

\section{Deinodrilus orcus sp. nov.}

[Fig. 11]

Material Examined. Holotype(H) AMNZ86029 (mature, 


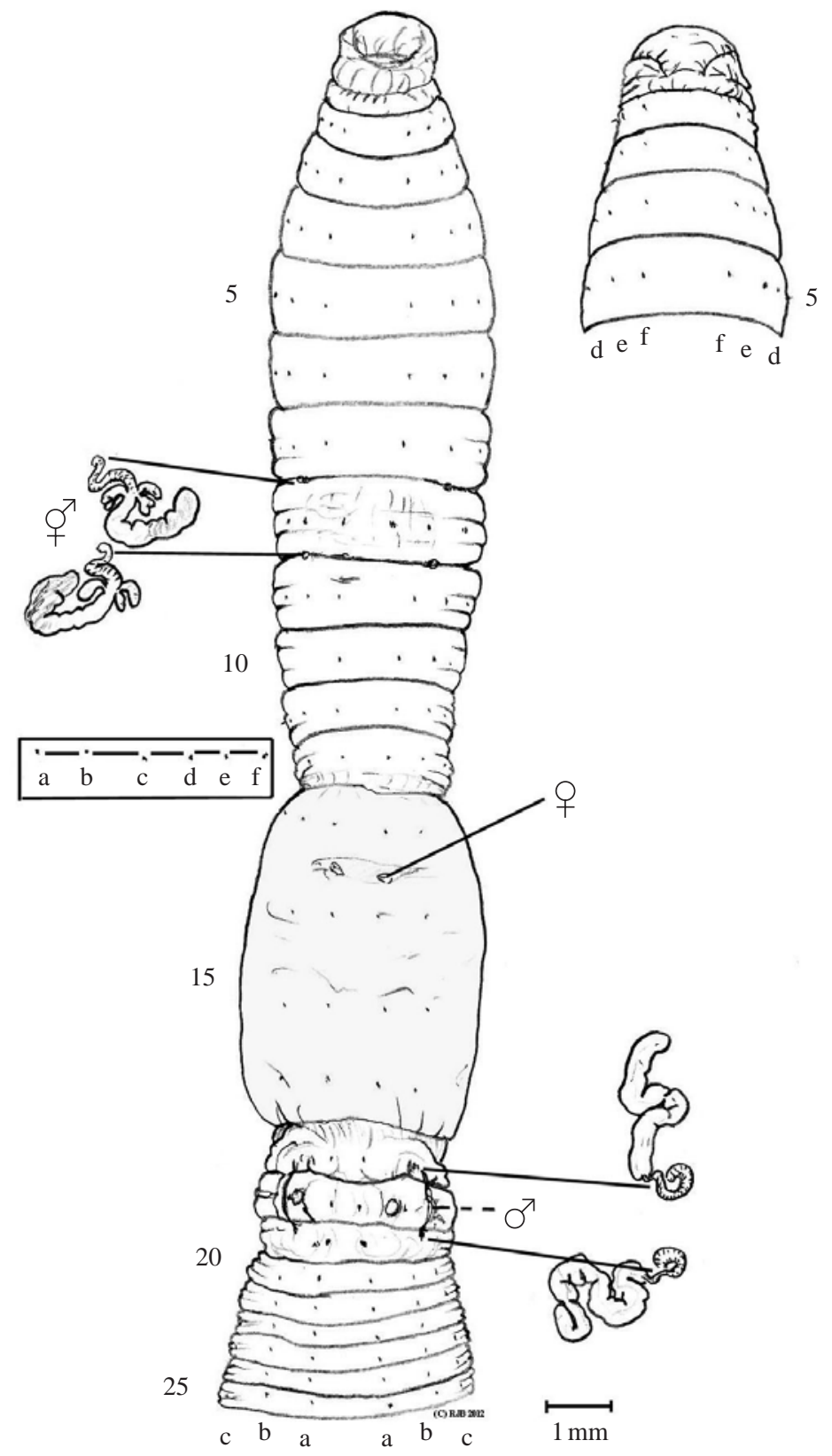

Fig. 11. Deinodrilus orcus Blakemore, sp. nov. Holotype AMNZ86029 showing dorsal view of prostomium and ventral aspect of body with spermathecae in $8 \mathrm{rhs} \& 9 \mathrm{rhs}$ and prostates in $17 \mathrm{rhs} \& 19 \mathrm{rhs}$ in situ. [Paratype setal ratios of $12 \mathrm{rhs}$ boxed].

sketched and dissected, in ethanol $80 \%$ and small tissue sample removed for DNA analysis, code WM4), Paratype (P), Te Papa W.002928 (mature that self-fragmented by autolysis into three bits induced by heat rather than handling; its anterior here dissected). Both specimens with same Mangamingi collection details as Rhododrilus mangamingi, but slightly deeper in scrub.

Etymology. After Roman god of the underworld and punisher of oath breakers (whence author J.R.R. Tokien partly derived the name for Orcs).
Diagnosis. Octochaetid with acanthodriline male and prostatic pores plus spermathecal pores in $7 / 8 / 9$, all in $b$ lines. Markings on 18 not pronounced. Gizzard in 6; calciferous glands lacking. Spermathecal diverticula four on each. mtDNA COI barcode as provided.

External characters. Anterior of the body circular. In life appears mottled white/red; preserved colour a delicate pastel pink-grey only slightly pigmented dorsally with faintly darker mid-dorsal line; clitellum paler buff. Length $88 \mathrm{~mm}$ with 150 segments $(\mathrm{H})$; Paratype in three 
fragments that combined add up to $80 \mathrm{~mm}$ and ca. 144 segments. Prostomium epilobous faintly closed $(\mathrm{H})$ or open (P). Setae perichaetine, 12 per segment, evenly spaced. Clitellum, annular, pale, tumid in 13-16 encroaching on adjacent segments slightly $(\mathrm{H}, \mathrm{P})$. Dorsal pores from 10/11 (H, P). Nephropores not found (meroic). Spermathecal pores in $b$ lines in $7 / 8$ and $8 / 9$, small but gaping. Female pores on 14 mid-way between setae a on 13 and 14 in common field. Prostatic pores approximately in position of setae b on 17 and 19 conjoined by seminal grooves shortly transecting intersegments $17 / 18$ and 18/ 19. Male pores within concave seminal grooves lateral to position of $b$ setae on 18. Segments 17-19 are tumid and setae are obscured in raised rectangular rim of male field. Genital markings not pronounced, although segment 8 is puckered ventrally (due to copulation) and there are distinct circular papillae just median to b setae on 18 ( $\mathrm{H}$ and $\mathrm{P})$. Genital and penial setae not found.

Internal morphology. Cerebral ganglion in 2. Septa all thin except perhaps 10/11 and 11/12. Crop in 5 (it appears that weak septum $5 / 6$ goes just below), strong muscular gizzard occupies 6-8 but seems actually in 6(weak septum 6/7 can be carefully teased off past mid-point at least). Dorsal blood vessel doubled in 6-18, at least. Heart paired in 10-13 (in P, unclear in H). Nephridia meroic; large equatorial clusters from 4 at least centred approximately in c-d lines, smaller on and after clitellum. Spermathecae in 8 and 9 each with a long, thin duct to multiple, finger-like diverticula (inseminated with mostly four per spermatheca in $\mathrm{H}$ and $\mathrm{P}$ but $9 \mathrm{lhs}$ in $\mathrm{H}$ has three and this plus some are bifid), surrounding duct from where it thickens before reaching yellowish, slightly dilated ampulla. Testes free, posterio-ventrally in 10 and 11 . Seminal vesicles large, racemose anteriorly in 11 and 12 from septa 10/11 and 11/12. Ovaries flattened fan-shaped in 13 with several strings; no ovisacs seen in 14. Prostates tubular in 17 and 19 exiting through muscular ducts, no penial setae found. Oesophagus thin in 8 and 9, slightly dilated and vascularized in 10,11-15 but not construed as calciferous glands, with intestinal origin somewhat indeterminate but after 16 (this region mascerated in $\mathrm{H}$ ). Intestinal typhlosole from around 19 ( $\mathrm{H}$ and $\mathrm{P}$ ) thin, lamellar becoming deeper further back. Intestine has masses of white 'lipid' sacs dorsally. Gut contains colloidal soil and organic matter (topsoil dweller/detritivore).

Ecology. Found in friable topsoil further into dense scrub than Rhododrilus mangamingi.

mtDNA results. megaBLAST highest max identity (95\%) on GenBank is observed with D. gorgon Blakemore, 2010 which is here considered sufficient divergence for specificity.

Remarks. Of the ten currently known Deinodrilus species, $D$. orcus comes morphologically closest to $D$. agilis Lee, 1952 from Waiotapu that is located nearby. The main differences are its seminal groves and male pores in mid$\mathrm{ab}$ rather than in b-lines as here, it further has five pairs of calciferous glands in 9-13 and dorsal pores from 16/17. Similar species are D. montanus Lee, 1952 from Rimutaka Range en route to Featherstone, also D. gorgon Blakemore, 2010 and D. medusa Blakemore, 2010 from Happy Valley on the South Island that, however, all have genital markings on 10, at least. Despite Lee's (1952b) description of these markings in D. montanus they are not shown in his plate 119 figure; but other differences are that dorsal pores are also given as from 16/17 and, furthermore, it lacks a typhlosole. In all these species, spermathecal diverticula number five except D. medusa that has four (or three) as here. Amongst other differing characteristics, $D$. medusa has seminal vesicles in 9-12. Molecular support for the current species is provided by its unique mtDNA COI barcode data in Appendix I.

Revival of genus Tokea Benham, 1904

Family MEGASCOLECIDAE s. stricto (Blakemore, 2000c)

Genus Tokea Benham, 1904

A chequered history of the genus was summarized by Benham (1942: 224) like this:

"As an illustration of this uncertainty, mention may be made of my genus Tokea (1905) [1904?]. In 1907 Michaelsen (p. 161) regarded this genus as really included in Megascolides. In 1916(according to Stephenson(1923, p. 193, and 1930, p. 835), for I have not access to the original paper, Michaelsen includes it in the genus Notoscolex on the ground of the microscopic structure of the prostate. Again, in 1910, Michaelsen (p. 36), in discussing the geographical distribution of these and related genera, refers repeatedly to the occurrence of Megascolides in New Zealand and Ceylon, but in 1916 comes to the conclusion that New Zealand earthworms formerly attributed to Megascolides must be removed from that genus to Notoscolex. Consequently New Zealand must be excluded from the geographical distribution of Megascolides. And so my Tokea has been shifted about, first as a subgenus of Megascolides in 1907 (p. 161), and then to Notoscolex in 1916. Now when our greatest authority on the Oligochaeta (unfortunately deceased) is so uncertain as to the limitation of the two genera, refers repeatedly to the occurrence, it is not surprising that Stephenson (who is likewise defunct), and who was, as his Monograph reveals, the next authority on the group, but who had followed Michaelsen, should have presented two opinions as to Tokea, for in 1930, p. 658, he refers to the edibility of 'Tokea(Megascolides),' while on p. 837 he wrote: 'Tokea must now go into Notoscolex.' Confusion worse confounded!" 
Lee (1952: 26) concluded that Tokea belonged in $\mathrm{Me}$ gascolides, explaining:

"Benham (1904) established a genus, Tokea, for several species from the North Island of New Zealand which had all the characters of Megascolides, but differed from that genus in one respect. The prostate had a simple central canal, but when sections of the gland were examined, it was found that the gland cells were grouped into small clusters which discharged their secretion into a slight evagination of the central duct. Benham called these small evaginations of the central duct 'canalicules'. It was unfortunate that he chose this term, since it really means a small canal and was taken as such by other workers, who placed Benham's species in Notoscolex. However, reference to the figures in Miss Sweet's paper on the structure of prostatic glands (1900), or to Benham's paper(1941) on Megascolides napierensis, in which he figures a crosssection of the prostate of Megascolides (Tokea) esculenta and details of the 'canalicules', will show what Benham meant by the term. I have examined sections of the prostatic gland of other genera of the family Megascolecidae and have found that these 'canalicules' are present in the prostates of other genera which have tubular prostates, e.g. in Neodrilus they are present in large numbers."

Benham (1904) did not explicitly select a type-species for his genus, however the exemplar he described first and in greater detail was Tokea esculenta, an edible native identified as "kurekure": a food reserved for Māori chiefs, and Michaelsen (1907: 161), if we accept he acted as 'First Reviser', seemingly accepted this as type-species. With no opportunity to inspect the type-specimen, Blakemore (2011) transferred it to genus Aporodrilus from $\mathrm{No}$ toscolex where it had resided following my revisions in 1999 (Blakemore, 2000a) on the assumption that its prostates were tubuloracemose because, having missed Lee's (1952) clarification above, I had taken Benham's original characterization of "tongue-shaped" glands having "canalicules" to mean they were non-tubular. This action inadvertently made Aporodrilus a temporary junior synonym of prior Tokea, albeit the remainder of the genus was still mostly subsumed in Notoscolex. Referring to information from Benham and Lee quoted above clarifies that, since the prostates actually qualify as tubular, Tokea indeed complies with Megascolides. However, lack of dorsal pores in the type, $T$. esculenta, gives precedent for restoration of the genus on the basis of this feature that, as it similarly separates Aporodrilus from Notoscolex (both with non-tubular prostates), now separates Tokea from Megascolides (both with tubular prostates).

In the appended checklist (Appendix II), those NZ species formerly qualifying for Tokea are restored having key characteristics of: lumbricine setae, avesiculate meroic nephridia, tubular prostates and being shown (or presumed) to lack dorsal pores. Tokea maorica Benham,
1904 (at least) has dorsal pores and is therefore returned as Megascolides maoricus (Benham, 1904), whilst Megascolides parvus Lee, 1952 lacks them so is newly transferred as Tokea parva (Lee, 1952).

Summary knowledge of $M$. orthostichon

Genus Megascolides M’Coy, 1878

\section{Megascolides orthostichon (Schmarda, 1861)}

[Fig. 12]

Synonymy. Hypogaeon orthostichon Schmarda, 1861a: 12, Plate 18, fig. 159.

Lumbricus orthostichon: Hutton, 1883: 586; Fletcher, 1886: 534.

Megascolides orthostichon: Beddard, 1892: 130; 1895: 496; Lee, 1959: 349; Lee, 1962: 175-176, figs. 11, 12 (of midriff and 9rhs spermatheca of non-type specimens, possibly of a different species); Blakemore, 2000c: 261-263, fig. 105; 2001: 5.

Notoscolex orthostichon: Michaelsen, 1900: 189; Benham, 1904a: 284, 1904b: 256.

Type Material. Listed by Reynolds \& Cook (1976: 148) as Hamburg Museum: 8615, although Beddard (1892a) inspected type material in the Vienna Museum, dissecting one specimen, and Beddard (1895: 496) later noted "I had only the type of SCHMARDA, which it was necessary to respect." Cole (1981) reports: firstly, that Beddard (1892) re-inspected Megascolides orthostichon (Schmarda, 1861) Vienna Museum type specimens of Hypogaeon orthostichon [4 specimens (=syntypes?)]; and secondly, that he found Perichaeta vitiensis Beddard, 1892 [=Pheretima (Pheretima) montana Kinberg, 1867] had a single specimen in the Vienna Museum mislabelled as "Hypogeon orthostichon Schm. Viti Ins. [=Fiji]".

Other material. London BM:1904:10:5:488/490, of unknown provenance from the British Museum 'Beddard Collection', (two clitellate matures, one entire and one dissected along the dorsal mid-line, plus three aclitellate specimens); these specimens were inspected by Lee (1962), but whether they were the correct taxon is uncertain. Furthermore, as non-type material, they would have no ICZN name-bearing function.

Remarks. The synonymy given above details available information on this species, as summarized in Blakemore (2000c), with its similarities discussed by Benham (1904b) and by Lee (1962: 176) who thought the nontype BM specimens he inspected resembled Tokea kirki Benham, 1904 (originally and currently in Tokea after a sojourn in Notoscolex or, at the time Lee was writing, in Megascolides-see Appendix II).

Since Megascolides orthostichon (Schmarda, 1861) 


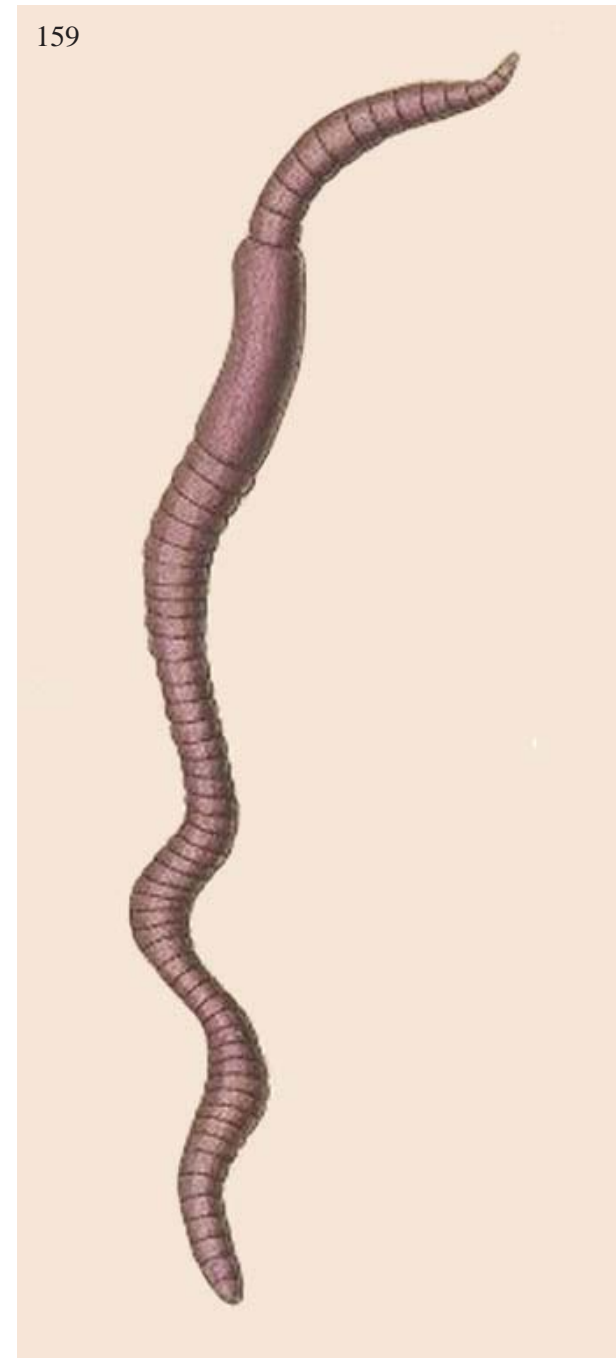

Fig. 12. Megascolides orthostichon (Schmarda, 1861) from his Plate XVIII, fig. 159.

was not relocated at its type-locality during the present brief survey, and neither is it known to have been reported on site for 150 years, it may thus qualify under DoC NZTCS (Molloy et al., 2002) classification as 'Nationally Critical', if not tagged 'Possibly Extinct' or even 'Extinct' under IUCN (2011) Redbook List Categories. No native earthworms were found at Mt Wellington thus it seems that pastoral cultivation particularly favours exotics. Further combined ecological and taxonomic (ecotaxonomic) survey is required to confirm or disconfirm this status and these conclusions.

\section{ACKnOWledgements}

Appreciation to staff of the University of Auckland (UA) Geothermal Energy team, especially Dr Sadiq Zarrouk and Dr Juliet Newson, along with Katherine Luketina of Waikato Regional Council, who helped facilitate some of these surveys on the ground. Curation of specimens is by John Early and Dhahara Ranatunga of Auckland Museum under the auspices of Research Chief, Dr Tom Trnski who kindly provided bench space and funded the DNA analyses. These most ably expedited (when Landcare declined the samples) by Ramon Gallego, a doctoral candidate in the Marine and Molecular Ecology Laboratories of UA. Te Papa curation is by Dr Bruce Marshall, and at National Museum of Nature and Science, Tokyo by Dr Toshiaki Kuramochi. Ancillary DNA data courtesy of TaeSeo Park at NIBR. Thanks to Dominic Bowden and Contact Energy staff for induction to Wairakei Geothermal steamfield; to the Tuaropaki trust Mokai, managers at Mangamingi, Hans \& Valerie van der Heiden at Golden Springs and to the Berry family (Russell, Annette and Mark) of Arataki Honey for kindly allowing access to their lands.

\section{REFERENCES}

Beddard, F.E. 1892. The earthworms of the Vienna Museum. Annals and Magazine of Natural History (6) 9:113-134.

Beddard, F.E. 1890. Observations upon an American species of Perichaeta and upon some other members of the genus. Proceedings of the Zoological Society, London 1890:5269.

Beddard, F.E. 1895. A monograph of the Order Oligochaeta. Clarendon Press, Oxford. pp. 769 [Available from: http:// www.us.archive.org/GnuBook/?id=monographoforder00 bedduoft\#8].

Benham, W.B. 1903. On a new species of earthworm from Norfolk Island. Transactions of the N.Z. Institute, Wellington 35:273-274 [Available from: http://www.archive. org/stream/transactionsproc35newz\#page/272/mode/2up].

Benham, W.B. 1904a. Some Earthworms from the North Island of New Zealand. Transactions and Proceedings of the Royal Society of New Zealand 37:281-285 [Available from: http://rsnz.natlib.govt.nz/volume/rsnz_37/rsnz_37_ 00_002960. html].

Benham, W.B. 1904b. On some Edible and other New Species of Earthworms from the North Island of New Zealand. Zoological Society of London 1904 (II):220-235 [Available from: www.archive.org/stream/proceedingsofzoo 19042zool\#page/256/mode/2up].

Benham, W.B. 1906. An Account of some Earthworms from Little Barrier Island. Transactions and Proceedings of the Royal Society of New Zealand 38:248-256 [Available from: http://rsnz.natlib.govt.nz/volume/rsnz_38/rsnz_38_ 00_003050.html].

Benham,W.B. 1942. Notoscolex equestris, an Earthworm from the Poor Knights Island. Transactions and Proceedings 
of the Royal Society of New Zealand 72:220-225 [Available from: http://rsnz.natlib.govt.nz/volume/rsnz_72/ rsnz_72_03_002070.html].

Blakemore, R.J. 1994. Earthworms of south-east Queensland and their agronomic potential in brigalow soils. Unpublished PhD Thesis, University of Queensland. $605 \mathrm{pp}$ [Available from: www.annelida.net/earthworm/PhD\%20 Thesis/PhDThesis.doc].

Blakemore, R.J. 1997. Two new genera and some new species of Australian earthworms (Acanthodrilidae, Megascolecidae: Oligochaeta). Journal of Natural History 31: 1785-1848.

Blakemore, R.J. 1999. The diversity of exotic earthworms in Australia-a status report. Proceedings of "The Other 99\%", W. Ponder \& D. Lunney (eds.), Transactions of the Royal Zoological Society of NSW 1999:182-187 [Available from: http://www.annelida.net/earthworm/Australasian\% 20Earthworms/Australian\%20Exotics.pdf].

Blakemore, R.J. 2000a. in Lee, K.E., Blakemore, R.J. and Fraser, P. (2000). Noke a Aotearoa-The Earthworms of NZ. The NZ Inventory of Biodiversity: A Species 2000 Symposium Review. Te Papa Museum, Wellington, NZ (Feb, 2000).

Blakemore, R.J. 2000b. Taxonomic and conservation status of earthworms from Lake Pedder, Tasmania Wilderness World Heritage Area. Records of the Queen Victoria Museum 109:1-36.

Blakemore, R.J. 2000c. Tasmanian Earthworms. CD-ROM Monograph with Review of World Families. ICZN (1999: Article 8) compliant CD-ROM. VermEcology, Kippax 2615. Canberra. 800 pp. including 222 figures.

Blakemore, R.J. 2002. Cosmopolitan Earthworms-an EcoTaxonomic Guide to the Peregrine Species of the World. VermEcology, PO BOX 414 Kippax, ACT 2615, Australia. 506 pp. including 80 figs.

Blakemore, R.J. 2003. Japanese Earthworms (Annelida: Oligochaeta): a Review and Checklist of Species. Organisms, Diversity and Evolution 3(3):241-244 [Available from: Electronic Supplement 2003-11 http://www.senc kenberg.de/odes/03-11.htm].

Blakemore, R.J. 2004. Checklist of New Zealand Earthworms updated from Lee (1959). In: A.G. Moreno \& S. Borges (eds.), Avances en taxonomia de lombrices de tierra/Advances in earthworm taxonomy (Annelida: Oligochaeta). Editorial Complutense, Universidad Complutense, Madrid, Spain. pp. 175-185.

Blakemore, R.J. 2006. A Series of Searchable Texts on Earthworm Biodiversity, Ecology and Systematics from Various Regions of the World. COE Soil Ecology Research Group, Yokohama National University, Japan. ICZN (1999: Article 8) compliant CD-ROM [Available from: http://www.annelida.net/earthworm/].

Blakemore, R.J. 2007. Origin and means of dispersal of cosmopolitan Pontodrilus litoralis (Oligochaeta: Megascole- cidae). European Journal of Soil Biology 43:S3-8 [Available from: http://dx.doi.org/10.1016/j.ejsobi.2007.08.041].

Blakemore, R.J. 2008. Cosmopolitan Earthworms. (3 ${ }^{\text {rd }}$ Edition). VermEcology, Yokohama, Japan. 757 pp.+ 243 figs.

Blakemore, R.J. 2009. Cosmopolitan earthworms-a global and historical perspective. Chapter 14. In: D.H. Shain (ed.), Annelids as Model Systems in the Biological Sciences, John Wiley \& Sons, Inc., N.Y. pp. 257-283.

Blakemore, R.J. 2010a. New zeal for new New Zealand earthworms (Acanthodrilidae, Octochaetidae, Megascolecidae, Lumbricidae: Oligochaeta: Annelida). ICZN (1999: Article 8) compliant CD-ROM. VermEcology, Japan. 55 pp.+ 14 figs.

Blakemore, R.J. 2010b. Cosmopolitan Earthworms-an EcoTaxonomic Guide to the Peregrine Species of the World. ( $4^{\text {th }}$ Edn.). VermEcology, Yokohama, Japan. $\sim 850$ pp. $+\sim 350$ figs.

Blakemore, R.J. 2011a. Breaking New Ground? Taupo Volcanic Zone Geothermal Earthworm Surveys. PG Certificate in Geothermal Energy Technology Project Report 2011.8, University of Auckland, N.Z. pp. 1-48.

Blakemore, R.J. 2011b. Further records on non-cryptic New Zealand earthworms. Zookeys. 160:23-46 [Available from: doi: 10.3897/zookeys.160.2354; http://www.pensoft. net/inc/journals/download.php?fileId=3688\&fileTable $=\mathrm{J}$ _GALLEYS].

Blakemore, R.J. and K.L. Elton. 1994. A hundred-year old worm? Australian Zoologist 29 (3-4): 251-254 [Available from: http://www.rzsnsw.org.au/publications/AZ29-34/AZ29-3-4_Blakemore_and_Elton_251-254.pdf].

Blakemore, R.J. and M.J. Grygier. 2011. Unravelling some Kinki worms (Annelida:Oligochaeta:Megadrili:Lumbricidae) Part III. Journal of Soil Organisms 83(2):231-244.

Buckley T.R., S. James, J. Allwood, S. Bartlam, D. Howitt and D. Prada 2011. Phylogenetic analysis of New Zealand earthworms (Oligochaeta: Megascolecidae) reveals ancient clades and cryptic taxonomic diversity. Molecular Phylogenetics and Evolution 58:85-96 [Available from: prepublication, Nov. 2010, and http://dx.doi.org/10.1016/j. ympev.2010.09.024].

Coles, J.W. 1981. Bibliography on the contributions to the study of the Annelida by Frank Evers Beddard with details of the material reported. Archives of Natural History 10(2): 273-315.

Csuzdi, Cs. and T. Pavlíček. 2002. Murchieona minuscula (Rosa, 1906), a new recorded earthworm from Israel, and distribution of genera Dendrobaena and Bimastos in Israel (Oligochaeta, Lumbricidae). Zoology of the. Middle East 25:105-114.

Fletcher, J.J. 1886. Notes on Australian Earthworms. Part I. Proceedings of the Linnean Society of NSW (2)1:523576.

Fletcher, J.J. 1889. Notes on Australian Earthworms. Part V. 
Proceedings of the Linnean Society of NSW (2)3:15211558.

Gates, G.E. 1965. On an Australian species of the earthworm genus Megascolex Templeton, 1844. Australian Zoologist 13(2):213-215.

Gates, G.E. 1972. Burmese Earthworms, an introduction to the systematics and biology of Megadrile oligochaetes with special reference to South-East Asia. Transactions of the American Philosophical Society 62(7):1-326.

Hutton, F.W. 1878. Catalogue of the hitherto described Worms of New Zealand. Transactions of the N.Z. Institute, XI., pp. 314-327, footnote, p. 317 [Available from: http://rsnz. natlib.govt.nz/volume/rsnz_11/rsnz_11_00_003010.pdf].

ICZN, 1999. International Code of Zoological Nomenclature. $4^{\text {th }}$ edn. Published by the International Trust for Zoological Nomenclature, c/o Natural History Museum, Cromwell Road, London, SW7 5BD, UK.

IUCN 2011. The IUCN Red List Categories and Criteria, Gland, Switzerland [Available from: http://www.iucnred list.org/technical-documents/categories-and-criteria; www.iucnredlist.org/documents/RedListGuidelines.pdf].

Lee, K.E. 1952a. Studies on the earthworm fauna of New Zealand-1. Transactions of the Royal Society of New Zealand 79:535-555 [Available from: rsnz.natlib.govt.nz/ volume/rsnz_79/rsnz_79_03_004320.html].

Lee, K.E. 1952b. Studies on the earthworm fauna of New Zealand-3. Transactions of the Royal Society of New Zealand 80:23-45 [Available from: rsnz.natlib.govt.nz/volume/ rsnz_79/rsnz_79_03_007250.html].

Lee, K.E. 1959. The earthworm fauna of New Zealand. New Zealand Department of Scientific \& Industrial Research Bulletin 130. 486 pp.

Lee, K.E. 1962. New Zealand earthworms in the collections of the British Museum (Natural History). Transactions of the Royal Society of New Zealand 2:169-180.

Lee, K.E. 1985. Earthworms-Their Ecology and Relationships with Soils and Land Use. Academic Press, Sydney. 411 pp.

Martin, N.A. 1977. Guide to the lumbricid earthworms of New Zealand pastures. New Zealand Journal of Experimental Agriculture 5:301-309.

Michaelsen, W. 1900. Das Tierreich, 10: Vermes, Oligochaeta. Friedländer \& Sohn, Berlin. 575 pp [Available from: In German http://www.archive.org/details/oligochaeta00 mich].
Michaelsen, W. 1907. Oligochaeta in Die Fauna SüdwestAustraliens. 1(2):117-232. Jena, Gustav Fischer [Available from: http://www.archive.org/details/diefauna sdwest $12 \mathrm{mich}]$.

Molloy, J., B. Bell, M. Clout, P. deLange, G. Gibbs, D. Given, D. Norton, N. Smith and T. Stephens. 2002. Classifying species according to threat of extinction. A system for New Zealand. Threatened Species Occasional Publication 22, Department of Conservation (Wellington). $26 \mathrm{pp}$. [Available from: http://www.doc.govt.nz/upload/docu ments/science-and-technical/TSOP22.pdf].

Reynolds, J.W. and Cook, D.C. 1976. Nomenclatura Oligochaetologica: A Catalogue of Names, Descriptions and Type Specimens of the Oligochaeta. University of New Brunswick, Fredericton, Canada. 216 pp.

Schmarda, L.K. 1861a. Neue Wirbellose Thiere Gesammelt auf einer Reiseun die Erde. Vol. 1(2). Verlag von Wilhelm Engelmann, Leipzig.

Schmarda, L.K. 1861b. Reise um die Erde in den Jahren 1853-1857, Volume 2. Braunschweig (Brunswick), Westermann. pp. 1-501 [Available from: on Google books, Jan., 2011].

Sims, R.W. and B.M. Gerard. 1999. Earthworms: Notes for the identification of British species. $4^{\text {th }}$ Edition. Published for The Linnean Society of London and The Estuarine and Coastal Sciences Association by Field Studies Council, Montford Bridge, Shrewsbury, UK. 169 pp.

Stephenson, J. 1930. The Oligochaeta. Oxford University, Clarendon Press. 978 pp.

Thomson, G.M. 1922. The Naturalisation of Animals \& Plants in New Zealand. Cambridge University Press. 607 pp.

Ude, H. 1905. Terricole Oligochäten von den Inseln der Südsee und von verschiedenen andern Gebieten der Erde. Zeitschrift für wissenschaftliche Zoologie LXXXIII: 405501 (In German).

Yeates, G.W., S.E. Spiridonov and R.J. Blakemore. 1998. Plesioungella kathleenae gen. n. et sp. n. (Nematoda: Drilonematoidea) from the Australian endemic megascolecid earthworm Fletcherodrilus unicus (Fletcher, 1889). New Zealand Journal of Zoology 25(2):205-212 [Available from: http://www.rsnz.org/publish/nzjz/1998/20.php].

Submitted: July 11, 2012, Accepted: August 24, 2012 
Appendix I. -mtDNA COI barcode FASTA data for species of concern.

Sample codes: 'RJBxx' courtesy of Dr T. Trnski AMNZ and Ramon Gallego UA (after Landcare declined); 'WMyy' courtesy T.S. Park, NIBR; and 'JETzz' courtesy of S. Prosser, N. Ivanova \& P. Hebert of iBOLD program at University of Guelph, Canada.

$>$ RJB07 AMNZ 5253 Notoscolex repanga Blakemore, 2011 H-old material nil result. $>$ RJB09 AMNZ 5254 Aporodrilus aotea Blakemore, 2011 H-old material nil result. $>$ RJB10 AMNZ 5255 Aporodrilus ponga Blakemore, 2011 H-old material nil result.

>RJB11_consensus_sequence Anisochaeta kiwi mihi H Golden Springs AMNZ 5260 AACCCTTTACTTTATTTTAGGAGTATGAGCCGGTATAATTGGTGCTGGCATAAGACTTCTTATTCGAATTGAATTAAGACAAC CTGGAGCATTTCTAGGAAGAGATCAATTATATAACACCATTGTTACTGCACATGCATTCTTAATAATTTTTTTCTTGGTAATA CCTGTATTTATTGGGGGATTTGGAAATTGACTGCTACCTCTTATACTAGGTGCTCCAGACATAGCATTCCCACGCCTTAATAA CATAAGATTTTGACTACTGCCCCCGTCACTAATTCTCCTAGTATCTTCTGCTGCAGTAGAAAAAGGAGCAGGAACAGGATGA ACAGTTTACCCACCCCTAGCAAGAAACATTGCTCATGCCGGGCCTTCGGTAGATCTAGCAATTTTCTCCCTTCATTTAGCTGG AGCATCATCAATTCTTGGCGCTATTAATTTTATTACAACAGTAATTAATATGCGGTGAACAGGACTACGCTTAGAGCGTATT CCCCTATTTGTATGGGCTGTAGTAATTACAGTTGTTCTTCTTCTCCTATCCCTACCAGTTCTAGCTGGAGCAATTACAATACT ACTAACAGATCGAAATCTAAATACATCATTCTTCGACCCTGCTGGAGGAGGTGATCCCATTCTATACCAACACCTATTT BLASTn alignment $A$. kiwi mihi $\mathrm{H}$ vs. A. $k$. kiwi $\mathrm{H}$ Identities=647/652 (99\%).

>RJB12_consensus_sequence $\boldsymbol{A}$. macleayi "S1" Wairakei AMNZ 5262

AACCCTATATTTCATTTTAGGAGTTTGAGCCGGTATAATTGGAGCCGGTATAAGGCTACTTATTCGAATTGAGTTAAGACAG CCAGGAGCATTTCTTGGAAGAGATCAACTATATAACACAATTGTAACTGCACATGCTTTCTTAATAATTTTTTTTCTAGTAAT ACCAGTATTTATTGGTGGTTTTGGAAATTGGCTTCTCCCACTCATACTAGGTGCACCAGATATAGCATTCCCACGACTTAATA ACATAAGATTTTGATTACTACCACCATCACTAATTTTACTTGTGTCGTCTGCTGCTGTGGAAAAAGGAGCTGGTACAGGATG AACAGTTTACCCCCCCCTTGCAAGAAACATTGCCCACGCTGGACCATCAGTAGACTTAGCAATTTTCTCACTTCACTTAGCTG GTGCCTCATCAATTCTAGGAGCTATCAACTTTATTACTACAGTAATTAATATACGATGAGCTGGACTACGTCTAGAACGAAT CCCACTATTTGTATGAGCTGTAGTAATTACAGTAGTTCTACTACTTCTATCTTTACCTGTACTTGCTGGGGCTATTACAATACT CCTAACAGATCGAAATCTAAATACTTCATTCTTTGACCCTGCCGGAGGAGGAGATCCAATTTTATATCAACACTTATTT

>RJB13_consensus_sequence $\boldsymbol{A}$. macleayi "S2" Wairakei AMNZ 5263

AACCCTATATTTCATTTTAGGAGTTTGAGCCGGTATAATTGGAGCCGGTATAAGGCTACTTATTCGAATTGAGTTAAGACAG CCAGGAGCATTTCTTGGAAGAGATCAACTATATAACACAATTGTAACTGCACATGCTTTCTTAATAATTTTTTTTCTAGTAAT ACCAGTATTTATTGGTGGTTTTGGAAATTGGCTTCTCCCACTCATACTAGGTGCACCAGATATAGCATTCCCACGACTTAATA ACATAAGATTTTGATTACTACCACCATCACTAATTTTACTTGTGTCGTCTGCTGCTGTGGAAAAAGGAGCTGGTACAGGATG AACAGTTTACCCCCCCCTTGCAAGAAACATTGCCCACGCTGGACCATCAGTAGACTTAGCAATTTTCTCACTTCACTTAGCTG GTGCCTCATCAATTCTAGGAGCTATCAACTTTATTACTACAGTAATTAATATACGATGAGCTGGACTACGTCTAGAACGAAT CCCACTATTTGTATGAGCTGTAGTAATTACAGTAGTTCTACTACTTCTATCTTTACCTGTACTTGCTGGGGCTATTACAATACT CCTAACAGATCGAAATCTAAATACTTCATTCTTTGACCCTGCCGGAGGAGGAGATCCAATTTTATATCAACACTTATTT BLASTn shows $100 \%$ match of A. macleayi $\mathrm{S} 2$ to S1 despite slight superficial differences.

>RJB18_consensus_sequence Anisochaeta kiwi kiwi H Mt Wellington AMNZ 5270

TTACTTTATTTTAGGAGTATGAGCCGGTATAATTGGTGCTGGCATAAGACTTCTTATTCGAATTGAATTAAGACAACCTGGA GCATTTCTAGGAAGAGATCAACTATATAACACCATTGTTACTGCACATGCATTCTTAATAATTTTTTTCTTGGTGATACCTGT ATTTATTGGGGGATTTGGAAATTGACTGCTACCTCTTATACTAGGTGCTCCAGACATAGCATTCCCACGCCTTAATAACATA AGATTTTGACTACTGCCCCCATCACTAATTCTCCTAGTATCTTCTGCTGCAGTAGAAAAAGGAGCAGGAACAGGATGAACAG TTTACCCACCCCTAGCAAGAAACATTGCTCATGCCGGGCCTTCGGTAGATCTAGCAATTTTCTCCCTTCATTTAGCTGGAGCA TCATCAATTCTTGGTGCTATTAATTTTATTACAACAGTAATTAATATGCGGTGAACAGGACTACGCTTAGAGCGTATTCCCCT ATTTGTATGAGCTGTAGTAATTACAGTTGTTCTTCTTCTCCTATCCCTACCAGTTCTAGCTGGAGCAATTACAATACTACTAA CAGATCGAAATCTAAATACATCATTCTTCGACCCTGCTGGAGGAGGTGATCCCATTCTATACCAACACCTATTT

>RJB19_consensus_sequence Anisochaeta kiwi kiwi P1 Mt Wellington AMNZ 5271

AACCCTTTACTTTATTTTAGGAGTATGAGCCGGTATAATTGGTGCTGGCATAAGACTTCTTATTCGAATTGAATTAAGACAAC CTGGAGCATTTCTAGGAAGAGATCAACTATATAACACCATTGTTACTGCACATGCATTCTTAATAATTTTTTTCTTGGTGATA CCTGTATTTATTGGGGGATTTGGAAATTGACTGCTACCTCTTATACTAGGTGCTCCAGACATAGCATTCCCACGCCTTAATAA CATAAGATTTTGACTACTGCCCCCATCACTAATTCTCCTAGTATCTTCTGCTGCAGTAGAAAAAGGAGCAGGAACAGGATGA ACAGTTTACCCACCCCTAGCAAGAAACATTGCTCATGCCGGGCCTTCGGTAGATCTAGCAATTTTCTCCCTTCATTTAGCTGG AGCATCATCAATTCTTGGTGCTATTAATTTTATTACAACAGTAATTAATATGCGGTGAACAGGACTACGCTTAGAGCGTATT CCCCTATTTGTATGAGCTGTAGTAATTACAGTTGTTCTTCTTCTCCTATCCCTACCAGTTCTAGCTGGAGCAATTACAATACT ACTAACAGATCGAAATCTAAATACATCATTCTTCGACCCTGCTGGAGGAGGTGATCCCATTCTATACCAACACCTATTT BLASTn shows $100 \%$ match of A. kiwi kiwi $\mathrm{H}$ to $\mathrm{P} 1$ despite superficial differences (cf. A. $k$ mihi).

[>WM6 NZ Arataki "Eisenia japonica" specimen AMNZ86031-shown to be mixed or contaminated. AAATAGGTGCTGATATAGAATAGGGTCTCCCCCGCCTGCAGGATCGAAGAATGATGTATTTAGGTTTCGGTCTGTTAGAAGT ATTGTAATAGCCCCAGCCAGTACGGGCAATGAGAGCAATAGAAGTACTACGGTAATAACCACTGCTCATACAAATAGGGGA ATTCGTTCTAATCGTAGTCCCGATCAGCGTATATTAATTACTGTGGTGATGAAGTTGATAGCCCCTAGAATTGAGGATGCTC CGGCTAAGTGGAGTGAGAAAATTGCTAGATCCACAGAAGGTCCAGCATGTGCAATATTTCTTGCTAGGGGTGGATATACCG TTCACCCGGTTCCTGCCCCCTTCTCTACTGCTGCTGAGGATACTAGTAAAATTAGAGACGGCGGTAGTAGTCAGAATCTTAT GTTATTTAGTCGTGGGAATGCTATGTCTGGTGTCCCCAATATAAGAGGTAGTAGCCAATTTCCAAAGCCCCCAATAAATACT GGTATAACTAAGAAAAAGATTATTAGAAATGCGTGTGCAGTAACAATTGTGTTGTATAGTTGATCGCTCCCTATAAAGGACC CGGGCTGCCTTAGCTCAATCCGAATAAGTAATCTTATCCCGGCACCCACCATGCCGGCCCAAATTCCTAAGATAAAATATAA 
Appendix I. Continued.

AGTTCC-BLASTn shows different to E. j. japonica (Identities $=527 / 657$ or $80 \%$ ) despite its morphological similarity and megaBLAST is $<85 \%$ similar to various megascolecids, thus this sample is considered contamination (Resamples as WO8/9 unsuccessful)].

>WM7 NZ Arataki Amynthas corticis specimen that provided DNA- AMNZ86033. GGTGTTGATATAAAATTGGGTCTCCCCCTCCTGCTGGATCAAAGAATGATGTATTAAGGTTTCGATCTGTTAATAGTATTGTG ATAGCACCGGCTAGTACTGGTAATGATAGAAGTAGTAGAACTACGGTAATTACTACTGCTCATACAAATAGGGGAATTCGT TCTAGTCGTAGGCCTGATCATCGTATATTAATTACTGTAGTAATAAAATTGATTGCACCTAGAATTGATGATGCCCCTGCTAA GTGTAGTGAGAAAATTGCCAGATCTACTGATGGTCCAGCATGCGCAATGTTACTTGCTAGTGGTGGGTAAACTGTTCATCCT GTTCCTGCACCTTTTTCCACTGCTGCAGAAGAGACTAGTAAGATGAGTGAGGGGGGTAATAGTCAGAATCTTATATTATTTA GGCGTGGAAATGCTATATCTGGAGTCCCCAATATAAGTGGTAATAGTCAATTACCAAAACCACCAATAAATACTGGTATTAC TAGAAAAAAAATTATTAAGAATGCATGTGCTGTTACAATTGTGTTATAAAGTTGGTCACTTCCCAGGAATGACCCAGGTTGT CTTAATTCGATTCGAATAAGAAGACTTATTCCAGCCCCAATTATTCCGGCTCAAATTCCTAAAATGAAGTATA - megaBLAST conforms $100 \%$ to A. corticis from Taiwan and "A. diffringens" from China; also with some of author's currently unpublished A. corticis spp-complex NIBR samples from Korea (Blakemore in prep.).

>JET10-17 Hamburg V119, 121 and Berlin Nr 2177 Eisenia japonica historical types-nil results.

> JET170-11|An-417|Enoshima Japan topotype Eisenia japonica japonica $\mid$ COI-5P

AACTTTATACTTTATCCTCGGAGTCTGAGCCGGGATAGTGGGTGCTGGTATAAGACTTCTCATTCGAATTGAATTGAGCCAG CCGGGAGCCTTCCTAGGAAGAGATCAACTATATAACACAATTGTAACAGCCCATGCATTTGTAATAATTTTCTTCTTAGTTAT ACCTGTATTCATTGGGGGTTTCGGAAACTGGCTACTTCCCTTAATACTAGGAGCCCCCGATATAGCCTTTCCACGACTTAACA ATATAAGATTCTGACTACTGCCCCCATCCCTTATCCTACTAGTATCCTCCGCCGCAGTAGAAAAAGGTGCAGGTACAGGATG AACGGTATATCCTCCTCTATCAAGAAATCTAGCACACGCAGGTCCTTCAGTTGATCTAGCCATTTTCTCACTTCATTTAGCGG GAGCTTCCTCAATTCTTGGGGCTATTAATTTTATCACTACAGTTATTAATATACGCTGAAGAGGACTACGATTAGAACGAAT CCCTTTATTCGTATGAGCTGTAGTAATTACAGTAGTTCTTTTACTTTTATCCCTCCCAGTACTTGCAGGAGCCATTACCATACT ACTAACAGATCGAAACTTAAATACTTCATTCTTCGATCCCGCAGGTGGTGGAGATCCAATTTTATACCAACATCTTTTC

>JET173-11|An-415| Hodogaya-ku Japan holotype Eisenia japonica hiramoto sub-sp. nov.|COI-5P GGGGTTTCGGAAACTGGTTACTTCCTTTAATACTAGGTGCCCCCGATATGGCCTTTCCACGACTCAACAATATAAGATTCTG GCTACTACCCCCATCCCTCATCCTACTCGTATCCTCCGCTGCAGTAGAAAAAGGGGCAGGTACGGGATGAACAGTATACCCT CCCCTATCAAGAAATCTAGCACACGCAGGTCCTTCAGTAGATCTAGCCATCTTTTCACTTCACTTAGCAGGAGCTTCCTCAAT TCTTGGAGCTATTAATTTTATCACTACAGTTATCAATATACGCTGAAGAGGCCTACGATTAGAACGAATTCCTTTATTCGTAT GAGCTGTAGTAATTACAGTAATTCTATTACTTCTATCCCTTCCAGTACTTGCAGGAGCCATTACCATATTACTAACAGATCGA AACTTAAATACCTCATTCTTCGATCCTGCAGG - BLASTn shows similarity no better than 93\% (Identities=414/445) with Enoshima E. japonica topotype An-417. megaBLAST shows similarity no better than $84 \%$ for lumbricids from Europe.

> JET174-11|HNHM-15529|Eisenia anzac Blakemore, 2011 Holotype from Japan, H|COI-5P

AACTTTATATTTTATTCTCGGTGTTTGAGCTGGTATAGTTGGTGCCGGTATAAGACTTCTAATTCGAATTGAACTAAGACAGC CGGGAGCCTTCCTAGGAAGAGATCAACTATACAATACAATTGTAACAGCTCATGCATTTGTTATAATTTTCTTTTTAGTAATA CCTGTATTTATTGGGGGATTTGGAAATTGATTACTTCCCCTAATACTAGGAGCCCCTGACATAGCCTTCCCACGACTAAACA ATATAAGATTCTGGTTACTTCCCCCGTCACTTATCCTCTTAGTATCTTCCGCTGCTGTAGAAAAAGGTGCAGGTACAGGATGA ACAGTATACCCCCCCTTATCAAGAAACCTTGCACATGCAGGTCCATCAGTAGATTTAGCCATCTTTTCTCTTCACCTGGCAGG AGCTTCTTCAATTCTGGGAGCTATTAACTTTATCACCACAGTTATCAACATACGTTGAAGAGGATTACGACTAGAACGAATT CCCCTATTTGTATGAGCTGTAGTTATTACAGTAGTCCTACTTCTTCTATCCCTCCCAGTGCTCGCAGGAGCCATTACCATGCT ACTTACAGATCGAAACTTAAATACTTCATTTTTCGACCCTGCCGGTGGTGGAGACCCTATCCTATACCAACATCTTTTC BLASTn E. anzac vs. E. $j$. hiramoto H Identities $=384 / 445$ (86\%); E. anzac vs. E. japonica An-417|Enoshima Japan topotype Identities= $569 / 658(86 \%)$.

>WM5 Rhododrilus mangamingi Holotype (H) AMNZ86028

TAAGTGTTGATATAAAATAGGGTCTCCTCCTCCTGAGGGATCGAAGAACGAGGTATTAAGGTTTCGATCTGTTAGTAGTATC GTAATAGCCCCAGCTAAAACTGGTAATGATAAAAGTAATAATACTACAGTAATAATAACGGCTCATACAAATAAGGGTACC CGTTCTAGGCGCATACCAGTTGATCGCATGTTGACAACTGTGGTAATAAAGTTAATTGCCCCTAAAATTGAGGAGGCACCAG CTAGGTGTAATGAGAAAATGGCAAGATCTACAGATGGCCCTGCATGGGCTATATTTCTAGCTAGTGGGGGATATACGGTTC ACCCAGTTCCAGCACCTTTTTCTACGGCAGCAGAGGATACTAGAAGGATTAGCGATGGGGGTAAAAGTCAAAATCTTATGTT ATTTAGTCGTGGAAATGCTATATCTGGTGCACCGAGTATTAAAGGTAGGAGTCAGTTTCCGAATCCACCAATAAATACTGGT ATTACTAAGAAGAAGATTATTAAAAATGCATGTGCTGTTACAATTGTATTATATAGTTGATCACTTCCTAGAAATGCTCCCG GCTGTCTTAATTCAATTCGAATTAAAAGTCTTATGCCGGCTCCAATTATTCCTGCCCACACTCCTAAGATAAAATA megaBLAST no closer than $84 \%$ for various worms, i.e., nothing similar yet sequenced on GenBank.

>WM4 Deinodrilus orcus Holotype (H) AMNZ86029

TGTTGATATAGAATAGGATCTCCTCCACCCGGAAGGATCAAAGAATGAGGTATTTAGATTTCGGTCTGTAAGGAGTATGGTA ATGGCACCAGCTAGTACTGGTAGGGATAGAAGAAGAAGTACTACTGTAATTAATACAGCTCATACAAATAAAGGAACTCGC TCTAGTCGTAGACCTGTCCACCGTATATTGATTACAGTTGTAATAAAGTTGATCGCTCCTAAAATAGATGATGCACCTGCTA GATGGAGTGAGAAAATTGCTAGATCTACTGATGGCCCAGCATGTGCAATATTTCTAGCTAGGGGAGGGTATACTGTTCACCC TGTTCCAGCTCCTTTTTCGACGGCTGCAGAGGATACTAGAAGAATTAGAGATGGAGGCAACAGTCAGAATCTTATGTTATTC AGTCGTGGGAATGCTATGTCTGGCGCTCCTAGTATTAATGGAAGGAGTCAGTTTCCAAACCCCCCAATAAATACCGGCATTA CTAAAAAGAAGATTATTAGAAATGCGTGCGCTGTAACAATTGTATTATATAGTTGATCGCTTCCTAGGAATGCCCCAGGTTG GCTTAATTCGATTCGGATTAATAGTCTTATTCCTGCCCCAATTATACCTGCTCAAATTCCTAAGATAAAATA - megaBLAST closest match is $95 \%$ for $D$. gorgon Blakemore, 2010 here considered sufficient for specificity. 
Appendix II. New Zealand Phylum Annelida, Subphylum Clitellata, Class Oligochaeta, Order Megadrilacea; families and genera after Blakemore (2000a; 2000b; 2000c; 2002; 2010a; 2010b), taxonomy following recommendations of ICZN (1999).

\begin{tabular}{|c|c|c|c|c|}
\hline FAMILY/Genus & Species name & $\begin{array}{l}\text { Species author, date } \\
\text { (genus author bold) }\end{array}$ & $\begin{array}{l}\text { Synonyms for native species and (some) genera, } \\
\text { plus specific status and occasional notes }\end{array}$ & Code* \\
\hline \multicolumn{5}{|c|}{ ACANTHODRILIDAE } \\
\hline Acanthodrilus & & Perrier, 1872 & & \\
\hline Acanthodrilus & kermadecensis & Lee, 1953 & & EK \\
\hline Acanthodrilus & ravus & $($ Lee, 1959) & Comb. nov. due to its J-shaped nephridial bladders & $\mathbf{E}$ \\
\hline Decachaetus & & Lee, 1959 & Eudinodriloides Lee, 1959 syn. nov. by Blakemore (2010a) & \\
\hline Decachaetus & erici & Blakemore, 2010 & & $\mathbf{E}$ \\
\hline Decachaetus & forsteri & $($ Lee, 1959) & Comb. nov. by Blakemore (2010a) & $\mathbf{E}$ \\
\hline Decachaetus & minor & Lee, 1959 & & $\mathbf{E}$ \\
\hline Decachaetus & violaceus & Lee, 1959 & & $\mathbf{E}$ \\
\hline Dinodriloides & & Benham, 1904 & & \\
\hline Dinodriloides & beddardi & Benham, 1904 & Dinodriloides annectens Benham, 1906 & $\mathbf{E}$ \\
\hline Diplotrema & & Spencer, 1900 & Eodrilus Michaelsen, 1907 & \\
\hline Diplotrema & annectens & (Beddard, 1889) & & $\mathbf{E}$ \\
\hline Diplotrema & bilboi & Blakemore, 2010 & & $\mathbf{E}$ \\
\hline Diplotrema & fallax & (Benham, 1909) & & $\mathbf{E}$ \\
\hline Diplotrema & haplocystis & (Benham, 1901) & & $\mathbf{E}$ \\
\hline Diplotrema & micros & $($ Lee, 1959) & & $\mathbf{E}$ \\
\hline Diplotrema & montana & (Lee, 1959) & & $\mathbf{E}$ \\
\hline Diplotrema & pallida & (Lee, 1959) & & $\mathbf{E}$ \\
\hline Diplotrema & paludosa & (Beddard, 1892) & & $\mathbf{E}$ \\
\hline Diplotrema & parva & $($ Lee, 1959) & & $\mathbf{E}$ \\
\hline Diplotrema & rossi & $($ Lee, 1959) & & $\mathbf{E}$ \\
\hline Maoridrilus & & Michaelsen, 1899 & & \\
\hline Maoridrilus & alpinus & Lee, 1959 & & $\mathbf{E}$ \\
\hline Maoridrilus & carnosus & Lee, 1959 & & $\mathbf{E}$ \\
\hline Maoridrilus & dissimilis & (Beddard, 1885) & Acanthodrilus neglectus Beddard, 1886 & $\mathbf{E}$ \\
\hline Maoridrilus & felix felix & Blakemore, 2010 & & $\mathbf{E}$ \\
\hline Maoridrilus & felix vallis & Blakemore, 2010 & & $\mathbf{E}$ \\
\hline Maoridrilus & fuscus & Lee, 1959 & & $\mathbf{E}$ \\
\hline Maoridrilus & gravus & Lee, 1959 & & $\mathbf{E}$ \\
\hline Maoridrilus? & intermedius & Michaelsen, 1924 & Species incertae sedis & $\mathbf{E}$ \\
\hline Maoridrilus? & mauiensis & Benham, 1904 & Species incertae sedis & $\mathbf{E}$ \\
\hline Maoridrilus & megacystis & Benham, 1919 & & $\mathbf{E}$ \\
\hline Maoridrilus & michaelseni & Ude, 1905 & & $\mathbf{E}$ \\
\hline Maoridrilus & minor & Lee, 1959 & & $\mathbf{E}$ \\
\hline Maoridrilus & modestus & Michaelsen, 1910 & & $\mathbf{E}$ \\
\hline Maoridrilus & montanus & Lee, 1959 & & $\mathbf{E}$ \\
\hline Maoridrilus & nelsoni & Lee, 1959 & & $\mathbf{E}$ \\
\hline Maoridrilus & pallidus & Lee, 1959 & & $\mathbf{E}$ \\
\hline Maoridrilus & parkeri & (Beddard, 1895) & & $\mathbf{E}$ \\
\hline Maoridrilus & plumbeus & (Beddard, 1895) & & $\mathbf{E}$ \\
\hline Maoridrilus & purus & Ude, 1905 & & $\mathbf{E}$ \\
\hline Maoridrilus & ruber & Lee, 1959 & & $\mathbf{E}$ \\
\hline Maoridrilus & rubicundus & Lee, 1959 & & $\mathbf{E}$ \\
\hline Maoridrilus & smithi & (Beddard, 1892) & & $\mathbf{E}$ \\
\hline Maoridrilus & suteri ama & Blakemore, 2010 & & $\mathbf{E}$ \\
\hline Maoridrilus & suteri suteri & Michaelsen, 1922 & & $\mathbf{E}$ \\
\hline Maoridrilus & tetragonurus & Michaelsen, 1899 & & $\mathbf{E}$ \\
\hline Maoridrilus? & thomsoni & Benham, 1919 & Species incertae sedis & $\mathbf{E}$ \\
\hline Maoridrilus & transalpinus & Lee, 1959 & Redescribed by Blakemore, 2010a & $\mathbf{E}$ \\
\hline Maoridrilus & uliginosus & (Hutton, 1877) & $\begin{array}{l}\text { Acanthodrilus novaezelandicae Beddard, 1885; } \\
\text { Acanthodrilus rosae Beddard, } 1889\end{array}$ & $\mathbf{E}$ \\
\hline Maoridrilus & ultimus & Lee, 1959 & & $\mathbf{E}$ \\
\hline Maoridrilus & volutus & Lee, 1959 & & $\mathbf{E}$ \\
\hline Maoridrilus & wilkini & Lee, 1959 & & $\mathbf{E}$ \\
\hline Microscolex & & Rosa, 1887 & $\begin{array}{l}\text { Photodrilus Giard, 1887, Deltania Eisen, 1893, } \\
\text { Notiodrilus Mich., } 1899\end{array}$ & \\
\hline Microscolex & aucklandicus auklandicus & (Benham, 1903) & From sub-Antarctic Auckland Isls. & $\mathbf{E}$ \\
\hline Microscolex & aucklandicus bollonsi & (Benham, 1909) & (Synonym of nominal subspecies?) & $\mathbf{E}$ \\
\hline Microscolex & aucklandicus pallidus & (Benham, 1909) & (Synonym of nominal subspecies?) & $\mathbf{E}$ \\
\hline
\end{tabular}


Appendix II. Continued.

\begin{tabular}{|c|c|c|c|c|}
\hline FAMILY/Genus & Species name & $\begin{array}{l}\text { Species author, date } \\
\text { (genus author bold) }\end{array}$ & $\begin{array}{l}\text { Synonyms for native species and (some) genera, } \\
\text { plus specific status and occasional notes }\end{array}$ & Code* \\
\hline Microscolex & campbellianus & (Benham, 1905) & & $\mathbf{E}$ \\
\hline Microscolex & dubius & (Fletcher, 1887) & Lee $(1962: 170,179)$ though it doubtful & ?A \\
\hline Microscolex & phosphoreus & (Dugès, 1837) & $\begin{array}{l}\text { Microscolex novazelandiae Beddard, } 1894 \\
\text { (corr. novaezelandiae) }\end{array}$ & $\mathbf{A}$ \\
\hline Neochaeta & & Lee, 1959 & & \\
\hline Neochaeta & forsteri & Lee, 1959 & & $\mathbf{E}$ \\
\hline Neochaeta & salmoni & Lee, 1959 & & $\mathbf{E}$ \\
\hline Neodrilus & & Beddard, 1887 & & \\
\hline Neodrilus & agilis & Lee, 1949 & & $\mathbf{E}$ \\
\hline Neodrilus & campestris & (Hutton, 1877) & Neodrilus monocystis Beddard, 1887 & $\mathbf{E}$ \\
\hline Neodrilus & dissimilis & Lee, 1959 & & $\mathbf{E}$ \\
\hline Neodrilus & edwardsi & Lee, 1959 & & $\mathbf{E}$ \\
\hline Neodrilus & polycystis & Lee, 1959 & & $\mathbf{E}$ \\
\hline Perieodrilus & & Michaelsen, 1910 & & \\
\hline Perieodrilus & lateralis & (Benham, 1903) & & $\mathbf{E}$ \\
\hline Perieodrilus & montanus & (Benham, 1903) & & $\mathbf{E}$ \\
\hline Perieodrilus & plunketi & (Benham, 1909) & & $\mathbf{E}$ \\
\hline Perieodrilus & ricardi & (Benham, 1903) & & $\mathbf{E}$ \\
\hline Plagiochaeta & & Benham, 1891 & & \\
\hline Plagiochaeta & lineata & (Hutton, 1877) & & $\mathbf{E}$ \\
\hline Plagiochaeta & stewartensis & Michaelsen, 1924 & & $\mathbf{E}$ \\
\hline Plagiochaeta & sylvestris & (Hutton, 1877) & $\begin{array}{l}\text { Plagiochaeta punctata } \text { Benham, } 1891 \\
\text { sometimes dated } 1892 \text { (valid synonym?) }\end{array}$ & $\mathbf{E}$ \\
\hline Rhododrilus & & Beddard, 1889 & Leptodrilus Benham 1909; Kayarmacia Jamieson, 1997 & \\
\hline Rhododrilus & aduncocystis & Lee, 1952 & & $\mathbf{E}$ \\
\hline Rhododrilus & agathis & Lee, 1959 & & $\mathbf{E}$ \\
\hline Rhododrilus & albidus & Lee, 1952 & & $\mathbf{E}$ \\
\hline Rhododrilus & aquaticus & Lee, 1959 & & $\mathbf{E}$ \\
\hline Rhododrilus & attenuatus & Lee, 1952 & & $\mathbf{E}$ \\
\hline Rhododrilus & benhami & Lee, 1952 & & $\mathbf{E}$ \\
\hline Rhododrilus & besti & Benham, 1904 & & $\mathbf{E}$ \\
\hline Rhododrilus & cockaynei & Benham, 1905 & $\begin{array}{l}\text { (Corr. } \text { R. cockayni); syn. Rhododrilus cockayni var. } \\
\text { waterfieldi Benham, } 1909\end{array}$ & $\mathbf{E}$ \\
\hline Rhododrilus & dobsoni & Lee, 1959 & & $\mathbf{E}$ \\
\hline Rhododrilus & edulis & Benham, 1904 & $\begin{array}{l}\text { Separate spermathecal openings as in } \\
\text { Hickmaniella classica } \text { Blakemore, } 2000\end{array}$ & $\mathbf{E}$ \\
\hline Rhododrilus & huttoni & (Benham, 1901) & & $\mathbf{E}$ \\
\hline Rhododrilus & insularis & Lee, 1959 & & $\mathbf{E}$ \\
\hline Rhododrilus? & intermedius & Lee, 1952 & Species incertae sedis (meroic?) & $\mathbf{E}$ \\
\hline Rhododrilus & kermadecensis & Benham, 1905 & Rhododrilus littoralis Jamieson, 1974 & EK \\
\hline Rhododrilus & leptomerus & Benham, 1905 & Leptodrilus magneticus Benham, 1909 & $\mathbf{E}$ \\
\hline Rhododrilus? & macroseptus & Lee, 1952 & Species incertae sedis (meroic?) & $\mathbf{E}$ \\
\hline Rhododrilus & mangamingi & Blakemore, 2012 & Sp. nov. & $\mathbf{E}$ \\
\hline Rhododrilus & microgaster & Lee, 1959 & & $\mathbf{E}$ \\
\hline Rhododrilus & minimus & Lee, 1952 & & $\mathbf{E}$ \\
\hline Rhododrilus & minutus & Beddard, 1889 & & $\mathbf{E}$ \\
\hline Rhododrilus & monticolus & (Beddard, 1895) & $\begin{array}{l}\text { Previously Microscolex monticola was species } \\
\text { incertae sedis, validated with gizzard in } 6 \text { not } 8 \\
\text { by Lee }(1962: 170)\end{array}$ & $\mathbf{E}$ \\
\hline Rhododrilus & papaensis & Lee, 1952 & & $\mathbf{E}$ \\
\hline Rhododrilus & parvus & Benham, 1906 & & $\mathbf{E}$ \\
\hline Rhododrilus & robustus & Lee, 1952 & & $\mathbf{E}$ \\
\hline Rhododrilus & rosae & Lee, 1959 & & $\mathbf{E}$ \\
\hline Rhododrilus & sexpapillatus & Dyne, 1980 & & $\mathbf{E}$ \\
\hline Rhododrilus & similis & Benham, 1906 & & $\mathbf{E}$ \\
\hline Rhododrilus & subtilis & Lee, 1959 & & $\mathbf{E}$ \\
\hline Rhododrilus & sutherlandi & Lee, 1952 & & $\mathbf{E}$ \\
\hline Rhododrilus & tetratheca & Lee, 1959 & & $\mathbf{E}$ \\
\hline Sylvodrilus & & Lee, 1959 & & \\
\hline Sylvodrilus & gravus & Lee, 1959 & & $\mathbf{E}$ \\
\hline
\end{tabular}


Appendix II. Continued.

\begin{tabular}{|c|c|c|c|c|}
\hline FAMILY/Genus & Species name & $\begin{array}{l}\text { Species author, date } \\
\text { (genus author bold) }\end{array}$ & $\begin{array}{l}\text { Synonyms for native species and (some) genera, } \\
\text { plus specific status and occasional notes }\end{array}$ & Code* \\
\hline \multicolumn{5}{|c|}{ OCTOCHAETIDAE } \\
\hline Deinodrilus & & Beddard, 1889 & $\begin{array}{l}\text { Dinodrilus (illegal emend.) Michaelsen, 1900; } \\
\text { Conicodrilus Benham, } 1945\end{array}$ & \\
\hline Deinodrilus & agilis & Lee, 1952 & & $\mathbf{E}$ \\
\hline Deinodrilus & benhami & Beddard, 1889 & & $\mathbf{E}$ \\
\hline Deinodrilus & gorgon & Blakemore, 2010 & & $\mathbf{E}$ \\
\hline Deinodrilus & gracilis & Ude, 1905 & & $\mathbf{E}$ \\
\hline Deinodrilus & kanieriensis & (Benham, 1945) & & $\mathbf{E}$ \\
\hline Deinodrilus & lateralis & Lee, 1959 & & $\mathbf{E}$ \\
\hline Deinodrilus & medusa & Blakemore, 2010 & & $\mathbf{E}$ \\
\hline Deinodrilus & montanus & Lee, 1952 & & $\mathbf{E}$ \\
\hline Deinodrilus & orcus & Blakemore, 2012 & Sp. nov. & $\mathbf{E}$ \\
\hline Deinodrilus & parvus & Lee, 1952 & & $\mathbf{E}$ \\
\hline Deinodrilus & suteri & Benham, 1906 & & $\mathbf{E}$ \\
\hline Dichogaster & & Beddard, 1888 & & \\
\hline Dichogaster & modiglianii & (Rosa, 1896) & Ude's (1905) record unconfirmed & ?A \\
\hline Hoplochaetina & & Michaelsen, 1920 & & \\
\hline Hoplochaetina & durvilleana & (Benham, 1919) & & $\mathbf{E}$ \\
\hline Hoplochaetina & pallida & Lee, 1952 & & $\mathbf{E}$ \\
\hline Hoplochaetina & polycystis & Lee, 1952 & & $\mathbf{E}$ \\
\hline Hoplochaetina & robusta & Lee, 1952 & & $\mathbf{E}$ \\
\hline Hoplochaetina & rossii & (Benham, 1903) & & $\mathbf{E}$ \\
\hline Hoplochaetina & rubra & Lee, 1959 & & $\mathbf{E}$ \\
\hline Hoplochaetina & spirilla & Lee, 1959 & & $\mathbf{E}$ \\
\hline Hoplochaetina & subtilis & Lee, 1959 & & $\mathbf{E}$ \\
\hline Leucodrilus & & Lee, 1952 & & \\
\hline Leucodrilus & digitocystis & Lee, 1952 & & $\mathbf{E}$ \\
\hline Leucodrilus & disparatus & (Lee, 1952) & Comb. nov. by Blakemore (2010a) & $\mathbf{E}$ \\
\hline Leucodrilus & fuscus & Lee, 1952 & & $\mathbf{E}$ \\
\hline Leucodrilus & robustus & Lee, 1959 & & $\mathbf{E}$ \\
\hline
\end{tabular}

\begin{tabular}{|c|c|c|c|c|}
\hline \multirow[b]{2}{*}{ Octochaetus } & \multicolumn{4}{|c|}{ non Yamaguchi, 1938) } \\
\hline & antarcticus & (Beddard, 1889) & & $\mathbf{E}$ \\
\hline Octochaetus & brucei & Lee, 1952 & & $\mathbf{E}$ \\
\hline Octochaetus & diememoratio & Blakemore, 2010 & & $\mathbf{E}$ \\
\hline Octochaetus & huttoni & Beddard, 1892 & & $\mathbf{E}$ \\
\hline Octochaetus & kapitiensis & Lee, 1959 & & $\mathbf{E}$ \\
\hline Octochaetus & kenleei & Blakemore, 2010 & & $\mathbf{E}$ \\
\hline Octochaetus? & levis & (Hutton, 1877) & Incertae sedis (Lee, 1959; 1962: 178) & ?E \\
\hline Octochaetus & michaelseni & Benham, 1904 & & $\mathbf{E}$ \\
\hline Octochaetus? & microchaetus & (Benham, 1950) & Incertae sedis; ex-type of Cryptochaeta & $\mathbf{E}$ \\
\hline Octochaetus & multiporus & (Beddard, 1885) & $\begin{array}{l}\text { Michaelsen (1900: } 319) \text { put } O \text {. thomasi Beddard, } \\
1893 \text { in synonymy; cf. Lee (1959: 115; 1962: 173) } \\
\text { who restored it }\end{array}$ & $\mathbf{E}$ \\
\hline Octochaetus & pelorus & Lee, 1959 & & $\mathbf{E}$ \\
\hline Octochaetus & ravus & Lee, 1959 & & $\mathbf{E}$ \\
\hline Octochaetus & sylvestris & Lee, 1952 & & $\mathbf{E}$ \\
\hline Octochaetus & thomasi & Beddard, 1893 & $\begin{array}{l}\text { Incertae sedis; sometimes dated " } 1892 " \text {; } \\
\text { spermathecal diverticula lack is questioned } \\
\text { (= syn. of } O \text {. multiporus?) }\end{array}$ & $\mathbf{E}$ \\
\hline Octochaetus & tricystis & Lee, 1952 & & $\mathbf{E}$ \\
\hline \multicolumn{5}{|c|}{ MEGASCOLECIDAE } \\
\hline Amynthas & corticis & (Kinberg, 1867) & $\begin{array}{l}\text { Syns. numerous (see Blakemore, 2010b) } \\
\text { probably including Pheretima clerica Benham, } \\
1946 \text { and } P \text {. campestris Lee, } 1952\end{array}$ & $\mathbf{A}+\mathbf{K}$ \\
\hline Amynthas & gracilis & (Kinberg, 1867) & & $\mathbf{A K}$ \\
\hline Amynthas & hupeiensis & (Michaelsen, 1895) & & $\mathbf{A}$ \\
\hline
\end{tabular}

Cryptochaeta Benham, 1950 [preocc. non Cryptochetum Rondani 1876 (Diptera)] synonymy by Lee(1959: 104); Adroitplema Blakemore, 2006 (nom. nov. pro Neodiplotrema Dyne, 1997 non Yamaguchi, 1938) ( 
Appendix II. Continued.

\begin{tabular}{|c|c|c|c|c|}
\hline FAMILY/Genus & Species name & $\begin{array}{l}\text { Species author, date } \\
\text { (genus author bold) }\end{array}$ & $\begin{array}{l}\text { Synonyms for native species and (some) genera, } \\
\text { plus specific status and occasional notes }\end{array}$ & Code* \\
\hline Anisochaeta & & Beddard, 1890 & $\begin{array}{l}\text { Trichaeta Spencer, 1900; } \\
\text { Spenceriella Michaelsen, 1907; } \\
\text { Gemascolex Edmonds \& Jamieson, 1973; } \\
\text { Pericryptodrilus Jamieson 1977; } \\
\text { Propheretima Jamieson, } 1995\end{array}$ & \\
\hline Anisochaeta & animae & $($ Lee, 1959) & (Dorsal pores present $>4 / 5$-pers. obs. Blakemore, 2011) & $\mathbf{E}(?)$ \\
\hline Anisochaeta & laingii & (Benham, 1903) & Sometimes misspelt "langii"" & ?A?K \\
\hline Anisochaeta & macleayi & (Fletcher, 1889) & New record New Zealand & A \\
\hline Anisochaeta & kiwi kiwi & Blakemore, sp. nov. & & $\mathbf{A}$ \\
\hline Anisochaeta & kiwi mihi & Sub-sp. nov. & & $\mathbf{A}$ \\
\hline Anisochaeta & novaezealandiae & (Lee, 1952) & $\begin{array}{l}\text { [Misspelt "novaezelandiae" in Reynolds \& } \\
\text { Cook (1979:146); and yet misformatted as originally } \\
\text { "novae-zealandiae" on www.boldsystems.org/ } \\
\text { views/taxbrowser.php?taxid=258680 (Oct. 2011)] }\end{array}$ & $\mathbf{E}$ \\
\hline Aporodrilus & & Blakemore, 2000 & Type: A. dombrovskisi Blakemore, 2000 & \\
\hline Aporodrilus & aotea & Blakemore, 2011 & & $\mathbf{E}$ \\
\hline Aporodrilus & equestris & (Benham, 1942) & Comb. nov. (Blakemore, 2011) & $\mathbf{E}$ \\
\hline Aporodrilus & mortenseni & (Michaelsen, 1924) & Comb. nov.(Blakemore, 2011) & ?E \\
\hline Aporodrilus & ponga & Blakemore, 2011 & & $\mathbf{E}$ \\
\hline Celeriella & & Gates, 1958 & & \\
\hline Celeriella & antarctica & (Baird, 1871) & $\begin{array}{l}\text { Type (BM 1845:6:18:1)-possibly first named } \\
\text { worm specimen collected from NZ 1841-1844 } \\
\text { by Dr Andrew Sinclair; syn. Diporochaeta shakespeari } \\
\text { Benham, } 1906 \text { by Lee (1962: 177) }\end{array}$ & $\mathbf{E}$ \\
\hline Celeriella & argillae & (Lee, 1959) & & $\mathbf{E}$ \\
\hline Celeriella & gigantea & (Benham, 1906) & & $\mathbf{E}$ \\
\hline Celeriella & pallida & (Lee, 1959) & Incertae sedis (tubuloracemose?) & $\mathbf{E}$ \\
\hline Didymogaster & & Fletcher, 1887 & & \\
\hline Didymogaster & sylvatica & Fletcher, 1887 & $\begin{array}{l}\text { NZ report of Australian sp doubted by } \\
\text { Stephenson (1930) \& Lee (1959: 261) }\end{array}$ & ?A \\
\hline Diporochaeta & & Beddard, 1890 & & \\
\hline Diporochaeta & aquatica & Benham, 1903 & & $\mathbf{E}$ \\
\hline Diporochaeta & brachysoma & Benham, 1909 & & $\mathbf{E}$ \\
\hline Diporochaeta & caswelli & Lee, 1959 & & $\mathbf{E}$ \\
\hline Diporochaeta & chathamensis & Benham, 1901 & & $\mathbf{E}$ \\
\hline Diporochaeta & duodecimalis & (Michaelsen, 1924) & & $\mathbf{E}$ \\
\hline Diporochaeta & heterochaeta & Benham, 1909 & & $\mathbf{E}$ \\
\hline Diporochaeta & intermedia & Beddard, 1889: 380 & $\begin{array}{l}\text { Perichaeta novae-zelandiae Beddard, } \\
\text { 1888: } 434 \text { (nomen nudum); } \\
\text { Diporochaeta novae-zelandia Beddard, 1890:55; } \\
\text { Diporochaeta intermedia taipo Jamieson, } 1976 \\
\text { (see www.bugz.org.nz) }\end{array}$ & $\mathbf{E}$ \\
\hline Diporochaeta & minima & Lee, 1959 & & $\mathbf{E}$ \\
\hline Diporochaeta & obtusa & Lee, 1952 & & $\mathbf{E}$ \\
\hline Diporochaeta & pounamu & Blakemore, 2010 & & $\mathbf{E}$ \\
\hline Diporochaeta & punctata & Lee, 1959 & "puctata” Reynolds \& Cook (1976: 160) & $\mathbf{E}$ \\
\hline Diporochaeta & radula & Blakemore, 2010 & (Suggested as a new genus "Radula") & $\mathbf{E}$ \\
\hline Graliophilus & & Jamieson, 1971 & & \\
\hline Graliophilus & parvus & (Lee, 1959) & & $\mathbf{E}$ \\
\hline Graliophilus & stewartensis & (Lee, 1959) & & $\mathbf{E}$ \\
\hline Megascolides & & M'Coy, 1878 & $\begin{array}{l}\text { Dinephrus Spencer, 1900: 33; } \\
\text { Austrohoplochaetella Jamieson, 1971; } \\
\text { Pseudocryptodrilus Jamieson, } 1972 \text { (obj. syn.), syns. } \\
\text { from Blakemore (2000c: 238), etc. }\end{array}$ & \\
\hline Megascolides? & albus & Lee, 1952 & (M. alba Lee, 1952, corr.); dorsal pores? & $\mathbf{E}$ \\
\hline Megascolides & fuscus & Lee, 1952 & & $\mathbf{E}$ \\
\hline Megascolides? & irregularis & Lee, 1952 & Dorsal pores not noted & $\mathbf{E}$ \\
\hline Megascolides & maoricus & (Benham, 1904) & $\begin{array}{l}\text { Restored as per Lee (1959). Syn. Tokea decipiens } \\
\text { Benham, 1905: } 241\end{array}$ & $\mathbf{E}$ \\
\hline Megascolides & neglectus & Cognetti, 1909 & Dorsal pores? & $\mathbf{E}$ \\
\hline Megascolides & orthostichon & (Schmarda, 1861) & Restored to NZ list. Dorsal pores? & $\mathbf{E}$ \\
\hline
\end{tabular}


Appendix II. Continued.

\begin{tabular}{|c|c|c|c|c|}
\hline FAMILY/Genus & Species name & $\begin{array}{l}\text { Species author, date } \\
\text { (genus author bold) }\end{array}$ & $\begin{array}{l}\text { Synonyms for native species and (some) genera, } \\
\text { plus specific status and occasional notes }\end{array}$ & Code* \\
\hline Megascolides? & raglani & Lee, 1952 & Dorsal pores not noted & $\mathbf{E}$ \\
\hline Megascolides & reptans & (Ude, 1905) & Dorsal pores? & $\mathbf{E}$ \\
\hline Megascolides & rubicundus & Lee, 1959 & $\begin{array}{l}\text { Misspelt "ribicundus" in Reynolds \& Cook, 1976: } 165 . \\
\text { Dorsal pores? }\end{array}$ & $\mathbf{E}$ \\
\hline Megascolides & unipapillatus & (Ude, 1905) & Dorsal pores? & $\mathbf{E}$ \\
\hline Notoscolex & & Fletcher, 1886 & $\begin{array}{l}\text { ?Nelloscolex Gates, 1939; } \\
\text { ?Lennoscolex Gates, 1960; } \\
\text { Pseudonotoscolex Jamieson, 1971; } \\
\text { Oreoscolex Jamieson, 1973; } \\
\text { Araucaridrilus, Jamieson, 2000; } \\
\text { ?Plutelloides Jamieson, } 2000 \text { (but cf. Megascolides) }\end{array}$ & \\
\hline Notoscolex & hakeaphilus & Benham, 1949 & & ?E \\
\hline Notoscolex & napierensis & (Benham, 1941) & & ?E \\
\hline Notoscolex & repanga & Blakemore, 2011 & & $\mathbf{E}$ \\
\hline Notoscolex & tasmani & (Lee, 1959) & Comb. nov.(Blakemore, 2011) & $\mathbf{E}$ \\
\hline Perionychella & & Michaelsen, 1907 & $\begin{array}{l}\text { Terrisswankerius Jamieson, 1994-for its putative type } \\
\text { Perichaeta canaliculata Fletcher, } 1887\end{array}$ & \\
\hline Perionychella & egmonti & $($ Lee, 1952) & & $\mathbf{E}$ \\
\hline Perionychella & helophila & (Benham, 1909) & Sic-originally Diporochaeta helophila & $\mathbf{E}$ \\
\hline Perionychella & ngakawau & Blakemore, 2010 & & $\mathbf{E}$ \\
\hline Perionychella & perionychopsis & (Benham, 1909) & & $\mathbf{E}$ \\
\hline Perionychella & shoeana & (Cognetti, 1912) & Sometimes miscited "P. shoeanus" & $\mathbf{E}$ \\
\hline Pontodrilus & & Perrier, 1874 & & \\
\hline Pontodrilus & lacustris & (Benham, 1903) & & $\mathbf{E}$ \\
\hline Pontodrilus & litoralis & (Grube, 1855) & $\begin{array}{l}\text { Pontodrilus matushimensis chathamianus } \\
\text { Michaelsen, 1899; (for other synonyms, see Blakemore, 2007) }\end{array}$ & $\mathbf{A}$ \\
\hline Perionyx & & Perrier, 1872 & & \\
\hline Perionyx & excavatus & Perrier, 1872 & $\begin{array}{l}\text { New record Australia by Blakemore (1994) and } \\
\text { NZ by Blakemore (2002) }\end{array}$ & $\mathbf{A}$ \\
\hline Tokea & & Benham, 1904 & Newly revived & \\
\hline Tokea & esculenta & Benham, 1904 & Newly restored type (no dorsal pores) & $\mathbf{E}$ \\
\hline Tokea & huttoni & Benham, 1904 & Dorsal pores not noted & $\mathbf{E}$ \\
\hline Tokea & kirki & Benham, 1904 & Dorsal pores not noted & $\mathbf{E}$ \\
\hline Tokea & parva & (Lee, 1952) & Comb. nov. (no dorsal pores) & $\mathbf{E}$ \\
\hline Tokea? & ruber & (Lee, 1952) & Comb. nov. (dorsal pores?) & $\mathbf{E}$ \\
\hline Tokea & sapida & Benham, 1904 & Dorsal pores not noted & $\mathbf{E}$ \\
\hline Tokea & suteri & Benham, 1904 & Dorsal pores not noted & $\mathbf{E}$ \\
\hline Tokea & urewerae & Benham, 1904 & Dorsal pores not noted & $\mathbf{E}$ \\
\hline Tokea & viridis & (Lee, 1952) & Comb. nov. (no dorsal pores) & $\mathbf{E}$ \\
\hline Zacharius & & Blakemore, 1997 & & \\
\hline Zacharius & aucklandicus & (Benham, 1909) & Comb. nov. (prostates non-tubular) & $\mathbf{E}$ \\
\hline Zacharius & obo & Blakemore, 2010 & & $\mathbf{E}$ \\
\hline \multicolumn{5}{|c|}{ GLOSSOSCOLECIDAE } \\
\hline Pontoscolex & corethrurus & (Müller, 1857) & $\begin{array}{l}\text { NZ records rediscovered by RJB } \\
\text { (see Michaelsen, 1900; Thomson, 1922) }\end{array}$ & $\mathbf{A}$ \\
\hline \multicolumn{5}{|l|}{ LUMBRICIDAE } \\
\hline Allolobophora & chlorotica sub-spp & (Savigny, 1826) & & $\mathbf{A}$ \\
\hline Allolobophoridella & eiseni & (Levinsen, 1884) & & $\mathbf{A}$ \\
\hline Aporrectodea & caliginosa & (Savigny, 1826) & & $\mathbf{A}$ \\
\hline Aporrectodea & longa & (Ude, 1885) & & $\mathbf{A}$ \\
\hline Aporrectodea & rosea & (Savigny, 1826) & & $\mathbf{A}$ \\
\hline Aporrectodea & trapezoides & (Dugès, 1828) & & $\mathbf{A}$ \\
\hline Aporrectodea & tuberculata & (Eisen, 1874) & & $\mathbf{A}$ \\
\hline Dendrobaena & attemsi & (Michaelsen, 1903) & New record New Zealand/Australasia & $\mathbf{A}$ \\
\hline Dendrobaena & veneta & (Rosa, 1886) & New record NZ by Blakemore (2002) & $\mathbf{A}$ \\
\hline Dendrodrilus & rubidus rubidus & (Savigny, 1826) & $\begin{array}{l}\text { Possibly including } D \text {. rubidus tenuis; } \\
\text { sometimes miscited as "Deinodrilus rubidus tenuis"! }\end{array}$ & A \\
\hline Dendrodrilus & rubidus subrubicundus & (Eisen, 1874: 51) & Listed by Lee(1959) as Dendrobaena subrubicunda & $\mathbf{A}$ \\
\hline Dendrodrilus & rubidus tenuis & (Eisen, 1874: 44) & Possibly a synonym of nominal species & $\mathbf{A}$ \\
\hline Bimastos & parvus & (Eisen, 1874) & Not confirmed from New Zealand & ?A \\
\hline
\end{tabular}


Appendix II. Continued.

\begin{tabular}{|c|c|c|c|c|}
\hline FAMILY/Genus & Species name & $\begin{array}{l}\text { Species author, date } \\
\text { (genus author bold) }\end{array}$ & $\begin{array}{l}\text { Synonyms for native species and (some) genera, } \\
\text { plus specific status and occasional notes }\end{array}$ & Code* \\
\hline Eisenia & fetida sub-spp & (Savigny, 1826) & $\begin{array}{l}\text { (Claimed E. fetida andrei Bouché, } 1972 \text { is probably } \\
\text { in synonymy of E. fetida and not confirmed from } \\
\text { New Zealand, nor elsewhere-see Blakemore, 2010b) }\end{array}$ & $\mathbf{A}$ \\
\hline Eisenia & japonica & (Michaelsen, 1892) & New record New Zealand/Australasia & $\mathbf{A}$ \\
\hline Eiseniella & tetraedra sub-spp & (Savigny, 1826) & See Blakemore (2010b) for details & $\mathbf{A}$ \\
\hline Lumbricus & castaneus & (Savigny, 1826) & & $\mathbf{A}$ \\
\hline Lumbricus & rubellus & Hoffmeister, 1843 & & $\mathbf{A}$ \\
\hline Lumbricus & terrestris & Linnaeus, 1758 & & $\mathbf{A}$ \\
\hline Murchieona & $\begin{array}{l}\text { minuscula (Rosa, 1906) } \\
\text { muldali }\end{array}$ & (Omodeo, 1956) & $\begin{array}{l}\text { New record New Zealand/Australasia Sometimes } \\
\text { combined or given separate species status } \\
\text { (see Blakemore, 2010b) }\end{array}$ & $\mathbf{A}$ \\
\hline Octolasion & cyaneum & (Savigny, 1826) & & $\mathbf{A}$ \\
\hline Octolasion & tyrtaeum lacteum & (Örley, 1881) & & $\mathbf{A}$ \\
\hline Octolasion & tyrtaeum tyrtaeum & (Savigny, 1826) & New record NZ by Blakemore (2010a) & $\mathbf{A}$ \\
\hline
\end{tabular}

*Codes: A=alien/exotic (synonymies in Blakemore (2010b); E=endemic/native; K=Kermadec Isls; ?=questionable. 